\title{
Alexandrium ostenfeldii growth and spirolide production in batch culture and photobioreactor
}

\author{
Walid Medhioub ${ }^{a, b, c}$, Véronique Sechet ${ }^{a}$, Philippe Truquet $^{a}$, Michèle Bardouil ${ }^{a}$, Zouher Amzil ${ }^{a}$, \\ Patrick Lassus ${ }^{\mathrm{a}}$, Philippe Soudant ${ }^{\mathrm{c}}$,
}

\author{
a Laboratoire Phycotoxines, IFREMER, Institut Français de Recherche pour l'Exploitation de la Mer, BP21105, \\ 44311 Nantes Cedex 3, France \\ b Laboratoire d'Aquaculture, INSTM, Institut National des Sciences et Technologies de la Mer, Route de Kniss, \\ 5000 Monastir, Tunisia \\ c LEMAR UMR 6539, IUEM-Université de Bretagne Occidentale, Place Nicolas Copernic, technopôle Brest Iroise, \\ 29280 Plouzané, France
}

\author{
*: Corresponding author : Philippe Soudant, Tel.: +33 2984986 23; fax: +33 298498645 \\ mail address : Philippe.Soudant@univ-brest.fr \\ Walid.Medhioub@ifremer.fr ; Veronique.Sechet@ifremer.fr ; Philippe.Truquet@ifremer.fr ; \\ Michele.Bardouil@ifremer.fr ; Zouher.Amzil@ifremer.fr ; Patrick.Lassus@ifremer.fr
}

\begin{abstract}
:
Growth and spirolide production of the toxic dinoflagellate Alexandrium ostenfeldii (Danish strain CCMP1773) were studied in batch culture and a photobioreactor (continuous cultures). First, batch cultures were grown in $450 \mathrm{~mL}$ flasks without aeration and under varying conditions of temperature (16 and $22{ }^{\circ} \mathrm{C}$ ) and culture medium $(\mathrm{L} 1, \mathrm{f} / 2$ and $\mathrm{L} 1$ with addition of soil extract). Second, cultures were grown at $16^{\circ} \mathrm{C}$ in $8 \mathrm{~L}$ aerated flat-bottomed vessels using $\mathrm{L} 1$ with soil extract as culture medium. Finally, continuous cultures in a photobioreactor were conducted at $18^{\circ} \mathrm{C}$ in $\mathrm{L} 1$ with soil extract; $\mathrm{pH}$ was maintained at 8.5 and continuous stirring was applied.
\end{abstract}

This study showed that $A$. ostenfeldii growth was significantly affected by temperature. At the end of the exponential phase, maximum cell concentration and cell diameter were significantly higher at $16{ }^{\circ} \mathrm{C}$ than at $22^{\circ} \mathrm{C}$. In batch culture, maximum spirolide quota per cell (approx. 5 pg SPX 13-desMeC eq cell ${ }^{-1}$ ) was detected during lag phase for all conditions used. Spirolide quota per cell was negatively and significantly correlated to cell concentration according to the following equation: $y=4013.9 x^{-0.858}$. Temperature and culture medium affected the spirolide profile which was characterized by the dominance of 13,19-didesMeC (29-46\%), followed by SPX-D (21-28\%), 13-desMeC (21-23\%), and 13-desMeD (17-21\%).

Stable growth of $A$. ostenfeldii was maintained in a photobioreactor over two months, with maximum cell concentration of $7 \times 10^{4}$ cells $\mathrm{mL}^{-1}$. As in batch culture, maximum spirolide cell quota was found in lag phase and then decreased significantly throughout the exponential phase. Spirolide cell quota was negatively and significantly correlated to cell concentration according to the equation: $y=12,858 x^{-0.8986}$. In photobioreactor, spirolide profile was characterized by higher proportion of 13,19 didesMeC (60-87\%) and lower proportions of SPX-D (3-12\%) and 13-desMeD (1.6-10\%) as compared to batch culture. 


\section{Highlights}

A. ostenfeldii growth was significantly affected by temperature but not by medium composition. Spirolide quota per cell was negatively and significantly correlated to cell concentration both in batch and photobioreactor cultures. - Spirolide profiles were affected by culture mode (batch vs photobioreactor).

Keywords: Alexandrium ostenfeldii ; Batch ; Growth ; Photobioreactor ; Spirolide production 


\section{Introduction}

Spirolides were first detected in mussels and clams from Nova Scotia (Canada) during spring and summer of 1991 (Richard et al., 2000 ; Sleno et al., 2004). Besides, these toxins were recently found in Spain (Villar Gonzalez et al., 2006), Italy (Ciminiello et al., 2006), Scotland (John et al., 2003), Norway (Aasen et al., 2005), Denmark (MacKinnon et al., 2006b) and France (Amzil et al., 2007).

Alexandrium ostenfeldii was identified as the primary source of spirolides, a novel group of macrocyclic imines characterized as marine fast-acting toxins (Cembella et al., 2000). Furthermore, the production of PSP toxins was also demonstrated for some A. ostenfeldii strains (Hansen et al., 1992; Mackenzie et al., 1996). Alexandrium ostenfeldii was considered as a cold-water mixotrophic species (Jacobson and Anderson 1996; Gribble et al., 2005), characterized by the presence of food vacuoles containing ciliates or phytoplankton residues (Jacobson and Anderson, 1996) and is known to be toxic to the tintinnid Favella ehrenbergii (Hansen et al., 1992). Moreover, some A. ostenfeldii strains can cause short-term toxic effects on heterotrophic dinoflagellates (Tillmann and John, 2002).

The $\mathrm{LD}_{50}$ of a mixture of spirolides, comprising mostly 13-desMeC, was determined to be 40 $\mu \mathrm{g} / \mathrm{kg}$ after intraperitoneal injection in mice and $1 \mathrm{mg} / \mathrm{kg}$ after oral administration (Richard et al., 2000). However, toxic effects in humans due to the ingestion of shellfish contaminated solely with spirolides have never been reported so far.

Great divergences were observed in spirolide toxin profiles among $A$. ostenfeldii in culture and in natural bloom isolates from different geographical regions. For example, the typical spirolide profile of isolates from the northeast Atlantic region often contain primarily 13desMeC, 13,19-didesMeC and 20-methyl G spirolides, but this is accompanied at the same time by considerable inter- and intrapopulation heterogeneity (Botana, 2008). The toxin profiles from plankton size fractions containing $A$. ostenfeldii and collected at Ship Harbor, Nova Scotia (Canada), were dominated by spirolides A, B, C, and 13-desMeC, whereas those collected at Graves Shoal, less than $100 \mathrm{~km}$ south, were remarkably different, with spirolides B, D, and isomer D2 as the major components (Cembella et al., 2001). A clonal culture isolate (AOSH1) from Ship Harbor yielded a profile similar to the natural mixed population dominated by 13-desMeC (Cembella et al., 1999; 2000) but another strain, $\mathrm{AOSH} 2$, isolated later on, produced primarily spirolide $\mathrm{C}$ and 20-methyl $\mathrm{G}$ (Cembella et al., 2007). MacKinnon et al. (2006a) identified two derivatives, spirolide $G$ and 13,19-didesMeG, in the Danish strains (LF37 and LF38). Major components of the toxin profile of cultured $A$. ostenfeldii from Limfjord, Denmark (CCMP1773) were spirolides 13,19-didesMeC and 13desMeC (Otero et al., 2010a,b). Finally, we note that strains CCMP1773, K0324 and LF37 are all the same isolate from Limfjord, Denmark with different isolate names.

The effects of environmental factors on Alexandrium ostenfeldii growth and toxin production are discussed in a few studies (Jensen and Moestrup 1997; John et al., 2001; Maclean et al., 2003; Ravn et al., 1995). Maclean et al. (2003) reported that $A$. ostenfeldii growth was related to environmental conditions, and strongly limited under sub-optimal light regimes (> $\left.150 \mu \mathrm{mol} \mathrm{m} \mathrm{m}^{-2} \mathrm{~s}^{-1}\right)$, salinity $(<15 \mathrm{psu})$ and low nutrients $(<20 \mu \mathrm{M}$ initial nitrate). These same authors suggested that the amount of spirolides synthesized by $A$. ostenfeldii increased in culture with cell concentration, but that spirolide amount per cell and toxin composition do not differ significantly in response to variations of the environmental parameters. Other authors showed that total toxin concentration in batch culture was affected by light intensity and photoperiod (John et al., 2001). Moreover, Ravn et al. (1995) showed that when $A$. ostenfeldii was cultured under conditions of limiting soil extract, cell division rate was reduced and toxin profile was modified. Finally, Jensen and Moestrup (1997) demonstrated that $A$. 
ostenfeldii maximum division rate occurred at $20^{\circ} \mathrm{C}$ and between 15 and 20 psu and that observed variations in cell size were related to temperature and salinity.

A ban on oyster sale recently occurred in Arcachon Bay (French S.W coasts). It was decided following positive mouse bioassays for the detection of lipophilic toxins. During this toxic event, chemical analysis conducted on Arcachon Bay oysters revealed the presence of spirolides. That is why attention has been recently focused on spirolides accumulation and elimination in and from oyster tissues. However, in order to perform contamination and detoxification trials on edible shellfish, it was necessary to grow $A$. ostenfeldii, a spirolide producer, at high cell concentrations and with known toxic profile and content. This requires a full technical and scientific understanding of $A$. ostenfeldii culture patterns.

In this paper, we examine $A$. ostenfeldii growth, toxin quota per cell and toxin profile (i) in batch culture to determine the effects of temperature and culture medium and (ii) in photobioreactors to develop procedures suitable for mass cultures.

\section{Materials and Methods}

\subsection{Micro-algae}

The harmful algal species used in this study was the CCMP1773 strain of Alexandrium ostenfeldii (Balech) isolated from Limfjord (Denmark) and obtained from the Provasoli Guillard National Center for Culture of Marine Phytoplankton. This strain was selected for its complex spirolide profile and the absence of PSP toxins (Otero el al., 2010a,b; Botana 2008; Ciminiello et al., 2006, 2010).

A. ostenfeldii was maintained in sea water enriched with $\mathrm{L} 1$ nutrients (Guillard and Hargraves, 1993), in $45 \mathrm{~mL}$ flasks at $16^{\circ} \mathrm{C}, 35 \mathrm{psu}$, and $155 \mu \mathrm{mol}$ photon $\mathrm{m}^{-2} \mathrm{~s}^{-1}$ provided by cool-white fluorescent lamps on $12 \mathrm{~h}: 12 \mathrm{~h}$ light:dark cycle in a culture room.

\subsection{Growth in batch cultures}

Initial cultures of $A$ ostenfeldii were grown in $450 \mathrm{~mL}$ culture flasks IWAKI ${ }^{\circledR}$ at 16 and $22^{\circ} \mathrm{C}$ using sterile sea water at a salinity of 35 psu and enriched with three media: $f / 2$ (Guillard and Ryther 1962, Guillard, 1975), L1 (Guillard and Hargraves, 1993), and L1 + soil extract at a concentration of $3 \mathrm{ml}$ per litre according to Ravn et al. (1995). Six experimental treatments were applied in triplicate, under a 16h:8h light:dark regime with a photon irradiance rate of $190 \mu$ mole $\mathrm{m}^{-2} \mathrm{~s}^{-1}$. These parameters were determined during the period of time where the strain was acclimated to our laboratory conditions.

Subsequently, $A$. ostenfeldii cultures were carried out using flat-bottomed vessels designed for $8 \mathrm{~L}$ cultures with aeration. All cultures were grown in triplicate in L1 medium (Guillard and Ryther 1962, Guillard, 1975), with soil extract added at the same concentration $\left(3 \mathrm{~mL} \mathrm{~L}^{-1}\right)$ and using sterile sea water at a salinity of $35 \mathrm{psu}$. Cultures were maintained at $16^{\circ} \mathrm{C}$ under a $12 \mathrm{~h}: 12 \mathrm{~h}$ light: dark regime and at a photon irradiance rate of $155 \mu$ mole $\mathrm{m}^{-2} \mathrm{~s}^{-1}$.

\subsection{Soil extract preparation}

The soil used to generate the extract was collected - according to Loeblich and Smith (1968) - from a natural environment rich in nutrients. No fungicides, insecticides, fertilizers, or other harmful compounds were present. First, the soil was sifted once through a coarse sieve 
$(1 \mathrm{~mm})$ to eliminate the dry ground and then through a fine sieve $(60 \mu \mathrm{m})$. Soil $(300 \mathrm{~g})$ was mixed in 600 millilitres of distilled water and autoclaved for 60 minutes at $121^{\circ} \mathrm{C}$. The solution was centrifuged at $4000 \mathrm{rpm}$ for 20 minutes and then supernatants were collected and filtered through $0.22 \mu \mathrm{m}$. Finally, sterile soil extract was divided into $15 \mathrm{~mL}$ tubes. These tubes were wrapped with parafilm to prevent bacteria contamination and then stored at $-20^{\circ}$ C.

\subsection{Culture in $100 \mathrm{~L}$ photobioreactor}

Alexandrium ostenfeldii was also cultured in $100 \mathrm{~L}$ bioreactors. Cells were inoculated at a concentration of approx. $8 \times 10^{3}$ cell $\mathrm{mL}^{-1}$ in sterile sea water at a salinity of 35 psu enriched with $\mathrm{L} 1+$ soil extract $\left(3 \mathrm{~mL} \mathrm{~L}{ }^{-1}\right)$. The bioreactors were made of $100 \mathrm{~L}$ polymethyl methacrylate stirred-tanks $(0.29 \mathrm{~m}$ diameter, $1.5 \mathrm{~m}$ length and $0.01 \mathrm{~m}$ container wall thickness). Cultures were stirred by 4-paddle impeller turbines at a rate of $50 \mathrm{rpm}$. The upper headplate of the bioreactors was designed to support all probes and tubing. An on-line $\mathrm{pH}-$ meter transmitted measurements to a central computer that controlled $\mathrm{pH}$ value by injecting $\mathrm{CO}_{2}$ into the bioreactors. The system was controlled by a computer equipped with a specific Visual Basic ${ }^{\circledR}$ software. The programme managed probe calibration and on-line recording of culture parameters. The reactors were placed in a room regulated at $18^{\circ} \mathrm{C}$ and submitted to a 16h:8h light regime and a $188 \mu$ mole $\mathrm{m}^{-2} \mathrm{~s}^{-1}$ of photon irradiance. Temperature was increased to reach $18^{\circ} \mathrm{C}$ and thus ensure a better cell growth in photobioreactor ( Beuzenberg et al. ,2007).

The system was adapted to continuous-flow culture by addition of a peristaltic pump supplying nutrients at a flow rate of $0.2 \mathrm{~mL} \mathrm{~min}^{-1}$ and another pump collecting overflow fractions.

\subsection{Analytical methods}

Aliquots $(5 \mathrm{~mL})$ of the cultures were taken to determine cell density with a Coulter-counter Multisizer ${ }^{\circledR}$ III. Cells concentrations were determined from: i) triplicate flask cultures in all treatments after $3,8,16$ and 20 days following inoculation; ii) triplicate flat bottomed vessel cultures at days $0,3,10,14$ and 18; and, iii) one photobioreactor culture during all culture phases (days $1,5,7,12,14,20,22,26,41,46,54,62,68,78,98,106,118$ and 132).

Growth rates $(\mu)$ during all phases were calculated following the equation (Guillard 1973).

$\mu=\left(\ln X_{t}-\ln X_{0}\right) / t$

where $X_{0}$ is the initial cell density and $X_{t}$ is the cell density after t days.

\subsection{Toxin analysis}

Spirolide production and composition were determined from $10 \mathrm{~mL}$ samples taken from: i) triplicate flask cultures in all treatments after 3,8 and 16 days following inoculation; ii) triplicate flat bottomed vessel cultures at days $0,3,10$ and 18; and, iii) one photobioreactor culture during all culture phases (days 1, 5, 7, 12, 14, 20, 26, 41, 46, 62, 78, 98, and 118).

Cells were collected by centrifugation $\left(4000 \mathrm{~g}, 10 \mathrm{~min}, 4^{\circ} \mathrm{C}\right)$, resuspended in $1 \mathrm{~mL}$ methanol/water $(95 / 5)$ and sonicated 20 min on ice with a Vibra Cell ${ }^{\circledR} 75115$ device. The extracts were collected in $2 \mathrm{~mL}$ eppendorf tubes and then frozen at $-80^{\circ} \mathrm{C}$. 
The LC-MS/MS analysis were performed according to Amzil et al, (2007) using a Shimadzu LC-20 AD XR ${ }^{\circledR}$ model coupled with a triple quadruple mass spectrometer (Q TRAP, API $4000^{\circledR}$ ) equipped with an electrospray ionisation source (ESI). Toxins were eluted in a $3 \mu \mathrm{m}$ hyperclone MOS C8 column (50X2.0mm, Phenomenex) at $20^{\circ} \mathrm{C}$ with a linear gradient set at $0.2 \mathrm{~mL} / \mathrm{min}$. The mobile phase consisted of two components (A) water and (B) acetonitrile/water (95:5), both containing $50 \mathrm{mM}$ formic acid and $2 \mathrm{mM}$ ammonium formate. Analyses were carried out in multiple reaction monitoring (MRM) positive ion mode and the two most intense produced ions per component were selected (Table 1).

In the present study, this method was used to detect and quantify known spirolides in $A$. ostenfeldii culture by comparing them with certified standards of 13-desMeC (NRCC, National Research Council (Canada). Good linear calibration data were obtained for spirolide standard in solution $\left(r^{2}=0.9958\right)$.

\subsection{Statistical analysis}

Experimental data were analysed using Statgraphics software. Effects of temperature and culture media on $A$. ostenfeldii growth (cell concentration and division rate), spirolide quota per cell and toxin profile were assessed using two-way ANOVA. Regression analyses were used to investigate the relationship between cell concentration and total spirolide quota per cell.

Growth rate and spirolide profile were arcsin-square $\operatorname{root}(\mathrm{x})$ transformed prior to statistical analysis but presented as untransformed data. Differences between means were considered statistically significant at $P \leq 0.05$.

\section{Results}

\subsection{Cell growth}

A. ostenfeldii growth in $450 \mathrm{~mL}$ flasks under different temperatures and culture medium conditions was characterized by low growth during the first 8 days followed by exponential growth which ended after 16-20 days of culture (Fig. 1). The highest cell concentrations were obtained after 20 days of culture at $16^{\circ} \mathrm{C}$ and after 16 days of culture at $22^{\circ} \mathrm{C}$. After 16 days of culture, cell concentration and growth rate were significantly different $(P<0.01)$ between the temperature treatments used $\left(16^{\circ} \mathrm{C}\right.$ and $\left.22^{\circ} \mathrm{C}\right)$. Addition of soil extract to the $\mathrm{L} 1$ medium resulted in slightly but not significantly higher maximum cell concentration and growth rate as compared to $L 1$ and $f / 2$ medium at both culture temperatures (Table 2 ).

Cells grown in the photobioreactor with aeration, agitation and $\mathrm{pH}$ regulation at $18^{\circ} \mathrm{C}$ showed the highest specific growth rate $\left(0.16 \mathrm{~d}^{-1}\right.$, Table 2$)$ and maximum cell concentration $\left(7 \times 10^{4}\right.$ cell $\mathrm{ml}^{-1}$ ) on day 106 (Table 2 \& Fig. 2).

\subsection{Changes in cell diameter during growth in batch and a photobioreactor cultures}

Growth of $A$. ostenfeldii in flask culture under different conditions showed that after 3 days of culture mean cell diameters ranged between 26 and $27 \mu \mathrm{m}$ with lower and upper limits corresponding to 17 and $40 \mu \mathrm{m}$ (Fig 3 and Fig $4 \mathrm{a}$, b). However, on day 8 and 16, $A$. ostenfeldii grown at $22^{\circ} \mathrm{C}$ showed a significant decrease $(\mathrm{P}<0.01)$ in mean cell diameters (ranging between 25 and $26 \mu \mathrm{m}$ at $D_{8}$ and between 23 and $24 \mu \mathrm{m}$ at $D_{16}$ ) as compared to mean diameter of cells grown at $16^{\circ} \mathrm{C}$ (ranging between 26 and $27 \mu \mathrm{m}$ at $D_{8}$ and $D_{16}$ ) (Fig 3). 
There were no significant differences in mean cell diameter $(P>0.05)$ between the three culture media regardless of culture days or temperature (Fig 3 ).

After 16 days culture, diameter of cells grown at $16^{\circ} \mathrm{C}$ showed one peak with cell diameter between 19 and $40 \mu \mathrm{m}$. However, at $22^{\circ} \mathrm{C}$, cells diameters showed two distribution modes (Fig 4a) : a first one located between 14 and $24 \mu \mathrm{m}$ and the second one between 24 and 40 $\mu \mathrm{m}$ (Fig 4b).

Significant decrease in $A$. ostenfeldii mean cell diameter was observed during growth in photobioreactor. The initial mean cell diameter was $28.5 \pm 0.03 \mu \mathrm{m}$ in the inoculum. After 26 days culture, mean cell diameter began to decrease and was $23.6 \pm 0.02 \mu \mathrm{m}$. At this time, $A$. ostenfeldii cell sizes showed three distribution modes. The first peak was located between 10 and $17 \mu \mathrm{m}$, the second between 17 and $23 \mu \mathrm{m}$ and the last between 23 and $40 \mu \mathrm{m}$ (Fig 5). Mean cell diameter continued to progressively decline during the exponential growth phase to reach $21.4 \pm 0.02 \mu \mathrm{m}$ on day 68 (Fig. 2). Conversely, cell concentration increased progressively over the same period (Fig. 2).

\subsection{Spirolide quota per cell}

Spirolide quota per cell (expressed as pg cell ${ }^{-1}$ ) in batch and a photobioreactor culture was inversely related to cell concentration according, respectively, to the equations: $y=4013.9 x^{-}$ 0.858 and $y=12858 x^{-0.8986}$ where $y^{\prime \prime}$ represents the spirolide quota per cell and $*$ " the corresponding cell concentration (Fig 6).

In all batch culture conditions used, total cellular spirolide concentration at day 3 was approx. 5 pg SPX eq 13-desMeC cell ${ }^{-1}$ and decreased steadily and significantly with culture age to reach low levels ranging between 1.3 and $2.4 \mathrm{pg}$ SPX eq 13-desMeC cell ${ }^{-1}$ at day 16 (Table $3)$. At this time, total spirolide production was significantly higher at $22^{\circ} \mathrm{C}$ than at $16^{\circ} \mathrm{C}$ regardless of medium composition $(\mathrm{P}<0.01)$. However, despite the different medium composition and temperature used, cell spirolide concentration was always significantly related to the cell concentration (Fig 7a,b).

Cells grown in $8 \mathrm{~L}$ aerated flat-bottomed vessels showed that total spirolides decreased with the age of the culture to reach $1.7 \mathrm{pg}$ SPX eq 13-desMeC cell ${ }^{-1}$ at day 18 (Table 3). Overall, total spirolide concentrations were similar to those obtained with $450 \mathrm{~mL}$ non aerated culture conditions.

Total spirolide quota per cell in a photobioreactor decreased rapidly during the first 14 days, i.e. from $4.7 \mathrm{pg}$ to $1.1 \mathrm{pg}$ SPX eq 13-desMeC cell ${ }^{-1}$ (Table 3). Then, total spirolide quota per cell continued to decrease steadily to reach $0.37 \mathrm{pg} \mathrm{SPX} \mathrm{eq} \mathrm{13-desMeC} \mathrm{cell}{ }^{-1}$ after 118 days of culture (Table 3).

\subsection{Spirolide concentration per culture volume}

Total spirolide concentration in batch and a photobioreactor culture (expressed as $\mu \mathrm{g} \mathrm{L}^{-1}$ ) showed a slight increase when cell concentration increase (Fig 8).

During the exponential phase of all batch cultures, 13,19-didesMeC concentration, showed a significant increase (approx. 2-fold) as cell concentration increased in the culture while meantime other components remained relatively stable (Fig 9).

In photobioreactor, spirolide concentration per unit of culture volume was higher than that obtained in batch culture, specifically the 13,19-didesMeC which was approx 5-fold higher 
(Fig 10). During exponential growth phase (until 41 days culture), only the 13,19-didesMeC showed an increase in concentration, while other components remained relatively stable (Fig 10). During stationary phase, concentration of 13,19-didesMeC in culture remained constant whereas other components showed a slight decrease (Fig 10).

\subsection{Spirolide profile}

Spirolide profile of $A$. ostenfeldii during growth in $450 \mathrm{~mL}$ culture flasks remained relatively stable regardless of temperature and culture media used. At the end of exponential phase, 13,19-didesMeC was slightly higher than the other components (between 29 and $46 \%$ ) followed by SPX-D, 13-desMeC and 13-desMeD in similar proportions (17-28\% ) (Table 3).

Spirolide profile of $A$. ostenfeldii grown in $8 \mathrm{~L}$ flat-bottomed vessels with $\mathrm{L} 1+$ soil extract at $16^{\circ} \mathrm{C}$ changed significantly according to the age of the culture. The proportion of 13,19 didesMeC increased steadily from $37 \%$ to $54.5 \%$ while, proportions of 13 -desMeC, SPX-D and 13 -desMeD decreased. The concentration of 13,19 -didesMeC was generally higher in $8 \mathrm{~L}$ aerated vessels than that obtained in $450 \mathrm{~mL}$ flask culture, (Table 3).

Spirolide profile of $A$. ostenfeldii grown in a photobioreactor with $\mathrm{L} 1+$ soil extract and at $18^{\circ} \mathrm{C}$ was dominated by 13,19 -didesMeC $(60-87 \%)$, followed by 13 -desMeC $(8-18 \%)$, SPX-D (3$12 \%)$, 13-desMeD (1.6-10\%) (Table 3$)$. This profile was drastically different from that obtained in batch cultures in term of proportions. However, as in batch culture, the 13,19dides $\mathrm{MeC}$ increased with the age of the culture and was above $80 \%$ the last 40 days of culture.

\section{Discussion}

This study provides new data on the effects of temperature, culture medium and culture mode on $A$. ostenfeldii growth, spirolide cell quota and profiles in both batch and photobioreactor cultures.

\subsection{Alexandrium ostenfeldii growth}

Growth of plant cells in culture is generally determined by environmental parameters such as nutrient availability, light, temperature (Boyer et al., 1987, Ogata et al., 1987, 1989; Anderson et al., 1990), salinity (White 1978), and trace components (Harrison et al., 1988; Okaishi et al., 1987; Wells et al., 1991). In the present study, the effects of medium composition and temperature were tested in batch culture.

\subsection{Effects of temperature and media culture}

The growth rate and maximum cell concentration of the dinoflagellate $A$. ostenfeldii were higher at $16^{\circ} \mathrm{C}$ than at $22^{\circ} \mathrm{C}$. Results contradict other studies where $A$. ostenfeldii optimum growth was obtained at $20^{\circ} \mathrm{C}$ and $15-20$ psu i.e: growth rate of $0.3 \mathrm{~d}^{-1}$ (Jensen et Moestrup, 1997).

In coastal environments, $A$. ostenfeldii has been found in such different geographical areas as Greenland (Ostenfeld et Paulsen, 1911) and New Zealand (Mackenzie et al., 1996). Unfortunately, data available from field studies concerning the ecology of $A$. ostenfeldii are limited. $A$. ostenfeldii has been observed at temperatures ranging from $-0.8^{\circ} \mathrm{C}$ (Ostenfeld et Paulsen, 1911) to approximately $16-20^{\circ} \mathrm{C}$ (summer water temperature in Denmark) (Jensen and Moestrup 1997). The better growth observed for cultures reared at $16^{\circ} \mathrm{C}$ agrees with the 
above-mentioned observations but also with culture experiments conducted with strains of $A$. ostenfeldii isolated from the Gulf of Maine (West Boothbay Harbor, USA). These strains grow well at $14^{\circ} \mathrm{C}$ under low light conditions, but reveal poor temperature tolerance above $16^{\circ} \mathrm{C}$ (Cembella et al., 2000).

There was no statistically significant differences in $A$. ostenfeldii growth (cell concentration and growth rate) due to culture medium composition ( $L 1, L 1+$ Soil Extract, $f / 2)$. This disagrees with the study of Ravn et al., (1995) where maximum cell concentration of $A$. ostenfeldii (strain LF R-287) was reduced under conditions of limited soil extract. Soil extract rich in humic acid was shown to promote the growth of different dinoflagellate species (Granéli and Moreira 1987; Hansen et al., 1992). However, as growth elicitation by soil extract was very mild in the present study, it is hypothesised that the absence of acclimation to culture medium before the experiment can be considered as a stress. This may have prevented the absorption of new components present in the medium. Another explanation for the lack of elicitation could relate to the type of soil that was used. As soil extracts are extremely variable and depending on where they are obtained, we can suggest that the soil extract used in this study was not rich enough in nutrients assumed to promote $A$. ostenfeldii growth.

\subsection{Photobioreactor culture}

Cultivation of $A$. ostenfeldii has already been obtained in photobioreactors using GP+selenium medium, 12h:12h light:dark cycle with $190 \mu$ mole photons $/ \mathrm{m}^{2} / \mathrm{s}, \mathrm{pH}$ control at 8.3 and at a temperature of $18^{\circ} \mathrm{C}$. Under these conditions cell concentrations as high as $2.9 \times 10^{4}$ cell $\mathrm{mL}^{-1}$ were achieved with low growth rate of $0.028 \mathrm{~d}^{-1}$ (Beuzenberg et al., 2007). The authors stated that this dinoflagellate grew faster and reached higher cell densities in the bioreactor than in carboy batch culture $\left(0.4 \times 10^{4}\right.$ cells $\mathrm{mL}^{-1}$ and $\left.0.012 \mathrm{~d}^{-1}\right)$. In the present study, A. ostenfeldii was grown and maintained in $100 \mathrm{~L}$ photobioreactor with aeration, agitation and $\mathrm{pH}$ control at 8.5. These conditions allowed $A$. ostenfeldii reaching concentrations between $6-7 \times 10^{4}$ cells $\mathrm{mL}^{-1}$ for more than 60 days with a growth rate of 0.16 $\mathrm{d}^{-1}$. A. ostenfeldii growth in a photobioreactor followed a pattern similar to that described for other species of dinoflagellates (Séchet et al., 2003). These authors reported that $A$. minutum originating from the North Atlantic and $A$. catenella from the Thau Lagoon (West Mediterranean coast) produced cultures with a relatively high division rate $\left(0.5 \mathrm{~d}^{-1}\right)$ and

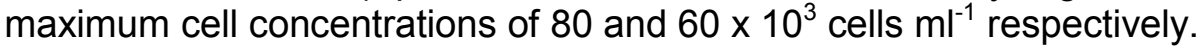

\subsection{Cell diameters}

Cell growth in flask culture at $22^{\circ} \mathrm{C}$ revealed a significant decrease in mean cell diameter compared to $A$. ostenfeldii inoculated at $16^{\circ} \mathrm{C}$. Our results are in agreement with Jensen and Moestrup (1997) who reported similar changes in cell diameter of $A$. ostenfeldii cultivated at different temperatures and salinities. According to these authors, mean cell diameter was closely correlated with division rate that changed according to investigated temperatures $\left(11.3-23.7^{\circ} \mathrm{C}\right)$ and salinities (10-30 psu). However, in our study, there was a positive relationship between mean cell diameter and growth rate. Culture maintained at $22^{\circ} \mathrm{C}$ resulted in smaller cells and lower division rate than that observed at $16^{\circ} \mathrm{C}$, probably because of stressful conditions induced by higher temperature.

Mean cell diameter of $A$. ostenfeldii also decreased significantly during culture in a photobioreactor approx. from $28 \mu \mathrm{m}$ to $21 \mu \mathrm{m}$. Cell diameters remained high during the first days $(27-29 \mu \mathrm{m})$ of exponential growth but decreased rapidly when maximal cell concentration was almost reached. Decrease in mean cell diameter is the consequence of the significant production of two smaller cell groups ranging between 10-17 $\mu \mathrm{m}$ and between $17-23 \mu \mathrm{m}$ corresponding together to approx. $44 \%$ of total population. 
We believe that reduction in cell diameter in both batch culture and a photobioreactor reflects production of temporary cysts. This is probably due to cellular stress provoked by variation in environmental factors such as high temperature (batch culture) and a combination of continuous agitation and $\mathrm{pH}$ regulation. Temporary cysts generally have a more variable and smaller size than vegetative cells (Jensen and Moestrup, 1997). Temporary cysts are very common under unfavourable culture conditions which do not allow good growth, such as agitation (Cembella et al., 2001), old cultures (Jensen and Moestrup, 1997), specific nutrients deficiencies (Anderson and Wall, 1978; Doucette et al., 1989; Fritz et al., 1989), changes in temperature (Schmitter, 1979), and bacterial attacks (Nagasaki et al., 2000).

\subsection{Total spirolide production and profile}

\subsubsection{Spirolide production}

Previous studies on $A$. ostenfeldii culture indicated high variability in total spirolide production per cell : 0.03-0.3 pg cell ${ }^{-1}$ (Maclean et al., 2003), $2.55 \mathrm{pg} \mathrm{cell}^{-1}$ (Otero et al., 2010) and $85 \mathrm{pg}$ cell $^{-1}$ (John et al., 2001). These variations are likely related to the strain of $A$. ostenfeldii used and to the environmental conditions applied.

The present study revealed that in all cultures spirolide quota per cell ranged between approx. 0.4 and $5 \mathrm{pg}$ SPX eq 13-desMeC cell $^{-1}$ and was negatively related to cell concentration under the different culture conditions used. Similarly, Beuzenberg et al. (2007) using a New Zealand strain obtained $7.1 \mathrm{pg} 13-$ desMeC cell $^{-1}$ in $15 \mathrm{~L}$ carboy batch culture and $1.5 \mathrm{pg} 13-\mathrm{desMeC}$ cell ${ }^{-1}$ in a photobioreactor with cell concentrations of 3800 cells. $\mathrm{L}^{-1}$ and 30000 cells. $L^{-1}$, respectively. This also suggests an inverse proportional relationship between cell concentration and spirolide quota per cell during $A$. ostenfeldii growth. Ichimi et al. (2002) also found an inverse relationship between PST toxin concentration per cell and growth rate, explaining that the decrease of cell toxicity is an indirect response to the increase in growth rate.

One may argue that such decrease of intracellular SPX may reflect its release into the extracellular medium throughout the culture cycle. Maclean et al. (2003) indicated that in batch cultures the proportion of extracellular spirolides was higher when $A$. ostenfeldii was grown in low nitrate conditions, suggesting that nutrient stress may affect leakage or excretion of these compounds, presumably due to higher cell mortality and loss of membrane integrity. During the first 25 days of culture, liquid-liquid extractions of extra-cellular medium were performed and analysis revealed a low proportion of spirolides (1 to $3 \%)$. John et al. (2001) also found a low concentration of spirolides in the culture medium $(<3 \%$ of the total spirolide of the whole culture). This indicates that extracellular spirolide accumulation do not accumulate even when cell numbers increase. Bacterial or enzymatic degradation or reassimilation of spirolides by the $A$. ostenfeldii cells can be speculated as factors limiting release or presence of SPX in the medium.

Spirolide concentration per litre of culture ranged from 11 to $15.5 \mu \mathrm{g} \mathrm{L}^{-1}$ and from 34 to $50 \mu \mathrm{g}$ $\mathrm{L}^{-1}$.It was positively related to the inoculum size (number of cells). As spirolide concentration per liter increased only slightly during the incubation period, most of the spirolides in the culture appeared to be synthesized when cells are transferred into fresh medium. This led to speculate that as cells divide spirolide concentration per cell is halved at each cell division. However, spirolide concentration per litre increased slightly during exponential phase, suggesting that spirolide production, most notably for the 13,19 - didesMeC, still occurs but at a low rate.

John et al. (2001) demonstrated that total spirolide concentration per volume of culture was directly related to cell and chlorophyll a concentrations, but also that spirolide concentration 
per cell or per litre was modulated by light:dark cycle. Spirolide quota per cell drastically increased at the beginning of the dark phase and decreased during the light phase. The authors reported that biosynthesis of these toxins is governed by light during cell division and that toxins are produced before cytokinesis (cell division).

Regarding the effect of temperature on $A$. ostenfeldii spirolide production, cells grown at $22^{\circ} \mathrm{C}$ had a higher total spirolide quota per cell compared to those grown at $16^{\circ} \mathrm{C}$ after 16 days of culture. But, this indeed reflects the higher division rate of cells maintained $a 6^{\circ} \mathrm{C}$. As mentioned before, decrease in mean diameter likely revealed encystment processes and thus an arrest of metabolic processes such as toxin production.

Nevertheless, above 4000 cells. $\mathrm{mL}^{-1}$, cells grown at $16^{\circ} \mathrm{C}$ tend to have higher cell quota than those maintained at $22^{\circ} \mathrm{C}$ suggesting that lower temperature would favour spirolide synthesis in addition to the initial quota produced at the time of culture inoculation.

There was no significant effect on spirolide production due to differences in culture media even with the addition of soil extract. Conversely, Ravn et al. (1995) showed that the use of soil extract in $A$. ostenfeldii culture is responsible for an increase in PSP concentration because of the stress provoked by the elicitor. But these authors noted that this increase was not systematically encountered.

\subsubsection{Spirolide profile}

Spirolide profiles in different $A$. ostenfeldii strains were assessed by several investigators (Otero et al., 2010; John et al., 2001 ; Maclean et al., 2003). However, the impact of different environmental parameters upon spirolide composition remains controversial. Otero et al. (2010a) reported that the type of spirolides produced by $A$. ostenfeldii is genetically dependent, but their proportions can vary considerably depending on external environmental factors. The authors reported that 13,19-didesMeC (81.1-97.6\%) and 13-desMeC (2.4$19.9 \%$ ) proportions were modulated by medium composition, salinity and photoperiod. However, other authors claimed that whatever environmental changes, toxin profile remains stable (John et al., 2001; Maclean et al., 2003).

In our study, spirolide analyses of $A$. ostenfeldii (strain CCMP1773) under different conditions and culture methods, revealed the presence of four analogues : 13,19-didesMeC, 13desMeC, 13-desMeD and SPX-D. The analogue 13,19-didesMeC, was the dominant component as previously reported by Otero et al. (2010a). Temperature $\left(16\right.$ and $22^{\circ} \mathrm{C}$ ) and culture medium composition ( $L 1, L 1+$ soil extract and $f / 2$ ) had little impact on spirolide analogue proportions. However, it is clear that culture mode can influence the profile of spirolides produced by $A$. ostenfeldii. In the photobioreactor culture, the percentage of 13,19 didesMeC was much larger (above $80 \%$ of total spirolides at the end of the culture) than in batch culture. The relative amount of 13-desMeC (approx. 15\%) was similar in both types of culture, while proportions of 13-desMeD and SPX-D in the photobioreactor were significantly lower than those observed in batch culture. This is the first evidence of a change in spirolide profile according to culture mode. Such variation could be due to physico-chemical factors such as cell agitation and $\mathrm{pH}$ regulation that characterize the photobioreactor functioning. These factors may promote cellular stress, and probably influence spirolide proportions.

A toxicological study performed by Mackinnon et al. (2006b) revealed that the loss of the methyl group at C-19 in 13-desMeC results in a 5-fold loss of toxicity. As 13,19-didesMeC is five times less toxic than spirolide 13-desMeC, cells grown in a photobioreactor with continuous stirring would become less toxic than cells grown in batch culture. For these reasons, further studies are needed to investigate the chemical or the physical factors that can directly influence $A$. ostenfeldii toxin profile. 
Although $A$. ostenfeldii has been grown successfully in high density using a photobioreactor, experimental conditions need optimisation. First, supplying culture media at a higher flow rate during the exponential phase could possibly achieve the maximum cell concentration in a shorter time. Second, to increase cell spirolide quota, we propose to increase nitrate concentration during stationary phase as $\mathrm{N}$ contributes to the generation of the imine function of spirolides. However, determination of intra and extracellular $\mathrm{N}: \mathrm{P}$ ratios in $A$. ostenfeldii experimental culture should be performed to investigate the relationship between nutrient availability and spirolide production.

Overall, further studies are needed to investigate the relationship between cell size, growth and spirolide production according to different environmental conditions and culture modalities (e.g. volume, aeration, agitation).

\section{Acknowledgments}

This work was supported by the convention framework between the Tunisian National Institute of Marine Science and Technologies (INSTM) and the French Research Institute for Exploitation of the Sea (IFREMER). Sincere thanks are due to A. Volety for English corrections.

\section{References}

Aasen, J., MacKinnon, S.L., LeBlanc, P., Walter, J.A., Hovgaard, P., Aune, T., Quilliam, M.A., 2005. Detection and identifi cation of spirolides in Norwegian shellfish and plankton. Chemical Research Toxicology.18: 509-515.

Amzil, Z., Sibat, M., Royer, F., Masson, N., Abadie, E., 2007. Report on the first detection of Pectenotoxin-2, Spirolide-A and their derivatives in French shellfish. Mar. Drugs 5, 168-179.

Anderson, D. M. and Wall, D.,1978. Potential importance of benthic cysts of Gonyaulax tamarensis and G. excavata in initiating toxic dinoflagellate blooms. J. Phycol., 14, 224-234.

Anderson, D.M., Kulis, D., Sullivan, J.J., Hall, S., Lee, C., 1990. Dynamic of physiology of saxitoxin production by the dinoflagellates Alexandrium spp. Mar. Biol. 104, 511-524.

Bates, S.S., 1998. Ecophysiology and metabolism of ASP toxin production. In: Anderson, D.M., Cembella, A.D., Hallegraef, G.M. (Eds.), Physiological Ecology of Harmful Algal Blooms, vol. 41. Springer-Verlag, Heidelberg, pp. 405-426 NATO-Advanced Study Institute Series.

Beuzenberg, V., Mountfort, D., MacKenzie, L., 2007. Enhancement of toxin production in photobioreactor culture systems for toxic micro-algae. Cawthron Institute, Nelson, New Zealand. in 6th International Conference on Molluscan Shellfish Safety Blenheim, New Zealand. Blackburn. 18-23 March 2007.

Botana, L.M., 2008. Seafood and Freshwater Toxins. Pharmacology, physiology and detection, Second edition (food science and technology). New York. 561-592.

Boyer, G. L., Sullivan, J. J., Andersen, R. J., Harrison, P. J., Taylor, F. J. R.,1987. Effects of nutrient limitation on toxin production and composition in the marine dinoflagellate Protogonyaulax tamarensis. Mar. Biol., 96: 123-128.

Cembella, A.D., 1998. Ecophysiology and metabolism of paralytic shellfish toxins in marine micro-algae. In: Anderson, D.M., Cembella, A.D., Hallegraef, G.M. (Eds.), Physiological Ecologyof Harmful Algal Blooms, vol. 41. Springer-Verlag, Heidelberg, pp. 381-404 NATO-Advanced Study Institute Series. 
Cembella, A.D., Lewis, N.I., Quilliam, M.A., 1999. Spirolide composition of micro-extracted pooled cells isolated from natural plankton assemblages and from cultures of the dinoflagellate Alexandrium ostenfeldii, Nat. Toxins 7(5), 197-206.

Cembella, A. D., Lewis, N. I., Quilliam, M., 2000. The marine dinoflagellate Alexandrium ostenfeldii (Dinophyceae) as the causative organism of spirolide shellfish toxins. Phycologia 39, 67-74.

Cembella, A.D., Bauder, A.G., Lewis, N.I., Quilliam, M.A., 2001. Association of the gonyaulacoid dinoflagellate Alexandrium ostenfeldii with spirolide toxins in size fractionated plankton. J. Plank. Res. 23, 1413-1419.

Cembella, A.D., Krock, B., 2007. Biogeography of spirolides in Alexandrium ostenfeldii from the North Atlantic-implications for shellfish toxicity and seafood safet, in 6th International Conference on Molluscan Shellfish Safety Blenheim, New Zealand. Blackburn SI, Bolch CJ, Lewis RJ, eds, Harmful Algal Blooms 2000. United Nations Educational, Scientific, and Cultural Organization, Paris, France, pp 383-386.

Ciminiello, P., Dell'Aversano, C., Fattorusso, E., Magno, S., Tartaglione, L., Cangini, M., Pompei, M., Guerrini, F., Boni, L., Pistocchi, R., 2006. Toxin profile of Alexandrium ostenfeldii (Dinophyceae) from the Northern Adriatic Sea revealed by liquid chromatography-mass spectrometry. Toxicon. 47: 597-604.

Ciminiello, P., Dell'Aversano, C., Dello lacovo, E., Fattorusso, E., Forino, M., Grauso, L., Tartaglione, L., Guerrini, F., Pezzolesi, L., Pistocchi, R., 2010. Charaterization of 27hydroxy-13-desmethyl spirolide $\mathrm{C}$ and 27-oxo-13,19-didesmethyl spirolide C. Further insights into the complex Adriatic Alexandrium ostenfeldii toxin profile. Toxicon. In press.

Doucette, G. J., Cembella, A. D. and Boyer, G. L., 1989 Cyst formation in the red tide dinoflagellate Alexandrium tamarense (Dinophyceae): Effects of iron stress. J. Phycol., 25, 721-731.

Estrada, M., Berdalet, E., 1998. Effects of turbulence on phytoplankton. In: Anderson D.M., Cembella A.D. and Hallegraeff G.M. (eds), Physiological Ecology of Harmful Algal Blooms. Springer-Verlag, Berlin, pp. 601-618.

Franks, P.J.S., 1997. Models of harmful algal blooms. Limnol. Oceanogr. 42, 1273 \pm 1282.

Fritz, L., Anderson, D. M. and Triemer, R. E., 1989. Ultrastructural aspects of sexual reproduction in the red tide dinoflagellate Gonyaulax tamarensis. J. Phycol., 25, 95107

Granéli, E., Olsson, P., Sundstrom, B., Edler, L., 1987. In situ studies of the effects of humic acids in dinoflagellates and diatoms. In Red Tides; Biol. Environ. Sci. Toxicol. Pror. Int. Symp. 1987. Edited by Okaichi, T., Anderson, D., Nemoto, T), pp. 209-212. Elsevier, New York.

Granéli, E., Flynn, K., 2006. Ecology of Harmful algae. In Granéli, E., Turner, T (Eds). Ecological Studies. Sprongler-Verlag Berlin Heidelberg, Vol.189: 229-241.

Gribble, K., Keafer, B., Quilliam, A., Cembella, A.D., Kulis, D., Manahan, A., Anderson, D., 2005. Distribution and toxicity of Alexandrium ostenfeldii (Dinophyceae) in the Gulf of Maine, USA. Deep-Sea Res II 52:2745- 2763.

Guillard R.R.L., Ryther J.H. 1962. Studies of marine planktonic diatoms. I. Cyclotella nana Hustedt and Detonula confervacea Cleve. Canadian Journal Microbiology 8, 229-239.

Guillard R.R.L. 1973. Division rates. In: Stein J.R. (ed.), Handbook of Phycological Methods. Cambridge Univ. Press, Cambridge, pp. 289-312.

Guillard R.R.L., 1975. Culture of phytoplankton for feeding marine invertebrates. In Smith, W.L. and Chanley. M.H. Culture of Marine Invertebrate Animals. Plenum Press, New York, USA, pp 26-60

Guillard, R.R.L., Hargraves, P.E., 1993. Stichochrysis immobilis is a diatom, not chrysophyte. Phycologia 32, 234-236.

Guisande, C., Frangopulos, M., Maneiro, I., Vergara, A.R., Isabel Riveiro, I., 2002 Ecological advantages of toxin production by the dinoflagellate Alexandrium minutum under phosphorus limitation. Mar. Ecol. Prog. Ser. 225:169-176. 
Hansen, P.J., Cembella, A.D., Moestrup, O., 1992. The marine dinoflagellate Alexandrium ostenfeldii: paralytic shellfish toxin concentration, composition, and toxicity to a tintinnid ciliate. J. Phycol., 28, 597-603.

Harrison, P.J., Yu P. W., Thompson, P.A., Price, N. M., Phillips, D.J., 1988. Survey of selenium requirements in marine phytoplankton. Mar; Ecol. Prog. Ser. 47, 89-96

Ichimi, K., Yamasaki, M., Okumura, Y., Suzuki, T., 2001. The growth and cyst formation of a toxic dinoflagellate, Alexandrium tamarense, at low water temperatures in northeastern Japan. J. Exp. Mar. Biol. Ecol. 261, 17-29.

Jacobson, D.M., Anderson, D.M., 1996. Widespread phagocytosis of ciliates and otherprotists by marine mixotrophic and heterotrophic thecate dinoflagellates. J. Phycol. 32,279-285.

Jensen, M., Moestrup.O., 1997. Autecology of the toxic dinoflagellate Alexandrium ostenfeldii: life history and growth at different temperatures and salinities. European Journal of Phycology 32: 9-18.

John, U., Quilliam, M.A., Medline, L., Cembella, A.D., 2001. Spirolide production and photoperiod-dependent growth of the marine dinoflagellate Alexandrium ostenfeldii. In Hallegraeff G.M., Blackburn, S.I., Bolch, C.J., Lewis, R.J, Eds. Harmful Algal Blooms 2000. United Nations Educational, Scientific and Cultural Organization, Paris, France, pp 299-302.

John, U., Cembella, A.D., Hummert, C., Elbrächter, M., Groben, R., Medlin, L.K., 2003. Discrimination of the toxigenic dinoflagellate species Alexandrium tamarense and Alexandrium ostenfeldii in co-occurring natural populations from Scottish coastal waters. European Journal of Phycology. 38: 25-40.

Juhl, A.R., Latz, M.I., 2002. Mechanisms of fluid shear-induced inhibition of population growth in a red-tide dinoflagellate. J. Phycol. 38: 683-694.

Konovalova, G. V.,1993. Toxic and potentially toxic dinoflagellates from the far east coastal waters of Russia. In Toxic Phytoplankton Blooms in the Sea (Smayda, T. J. \& Shimizu, Y., editors), 275-279. Elsevier, Amsterdam.

Loeblich, A. R., Smith, V. E. (1968) Chloroplast pigments of the marine dinoflagellate Gyrodinium resplendens. Lipids 8, 5--13 (1968).

MacKenzie, L., White, D., Oshima, Y., Kapa, J., 1996. The resting cyst and toxicity of Alexandrium ostenfeldii (Dinophyceae) in New Zealand. Phycologia 35, 148-155.

MacKinnon, S.L., Cembella, A.D., Burton, I.W., Lewis, N., LeBlanc, P., Walter, J.A., 2006a. Biosynthesis of 13-desmethyl spirolideC by the dinoflagellate Alexandrium ostenfeldii. $\mathrm{J}$ Org Chem 71:8724-8731.

MacKinnon, S.L., Walter, J.A., Quilliam, M.A., Cembella, A.D., Leblanc, P., Burton, I.W., Hardstaff, W.R., Lewis, N.I., 2006b. Spirolides isolated from Danish strains of the toxigenic dinoflagellate Alexandrium ostenfeldii. J Nat Prod 69:983-987

Maclean, C., Cembella, A.D., Quilliam, M.A., 2003. Effects of light, salinity and inorganic nitrogen on cell growth and spirolide production in the marine dinoflagellate Alexandrium ostenfeldii (Paulsen) Balech et Tangent. Botanica Marina 46(5), 466-476.

McLachlan, J.I., Marr, J.C., Conolon-Kelly, A., Adamson, A., 1994 Effects of nitrogen concentration and cold temperature on DSP-toxin concentration in the dinoflagellate Prorocentrum lima (Prorocentrales, Dinophyceae). Natural Toxins 2:263-270.

Mortensen, A. M., 1985. Massive fish mortalities in the Faroe Islands caused by a Gonyaulax excavata red tide. In Toxic Dinoflagellates (Anderson, D. M., White, A. W. \& Baden, D. G., editors), 165-169. Elsevier, Amsterdam.

Nagasaki, K., Yamaguchi, M. and Imai, I., 2000. Algicidal activity of a killer bacterium against the harmful red tide dinoflagellate Heterocapsa circularisquama isolated from Ago Bay, Japan. Nippon-Suisan-Gakkaish, 66, 666-673.

Navarro, J.M., Muñoz, M.G., Contreras, A.M., 2006. Temperature as a factor regulating growth and toxin content in the dinoflagellate Alexandrium catenella. Harmful Algae 5:762-9.

Ogata, T., Ishimaru, T., Kodama, M., 1987. Effect of water temperature and light intensity on growth rate and toxicity change in Protogonyaulax tamarensis. Mar. Biol. 95, 217-220. 
Ogata, T., Kodama, M., Ishimaru, T., 1989. Effect of water temperature and light intensity on growth and toxin production of toxic dinoflagellate. In Red Tides: boil. Environ. Sci. Toxicol. Proc. Int. Sym. 1987. New York. Pp.423-426.

Okaishi, T., Montani, S., Hiragi, J., Hasui, A., 1987. The role of iron in the outbreaks of Chattonella red tide. In Red Tides. Biol. Environ, Sci, Toxicol. Proc. Int. Symp. 1987. Edited by Okaichi, T., Anderson, D., Nemoto, T), pp. 353-356. Elsevier, New York.

Ostenfeld, C.H., Paulsen, O.,1911. Marine Plankton from the East- Greenland Sea. IV. General remarks on the microplankton. Danmarks-ekspeditionen til Gronlands Nordostkyst 1906-1908, vol. III, no. 11.

Otero, P., Alfonso, A., Vieytes, M.R., Cabado, A.G., Vieites, J.M., Botana, L.M., 2010a. Effects of environmental regimens on the toxin profile of Alexandrium ostenfeldii. Environmental Toxicology and Chemistry, 29, 301-310.

Otero, P., Alfonso, A., Alfonso, C., Vieytes, M.R., Louzao, M.C., Botana, A.M., Botana, L.M., $2010 \mathrm{~b}$. New protocol to obtain spirolides from Alexandrium ostenfeldii cultures with high recovery and purity. Biomedical Chromatography, doi:10.1002/bmc.1380.

Ravn, H., Schmidt, U.C., Sten, H., Anthoni, U., Christophersen, C., Nielsen, H.P., 1995. Elicitation of Alexandrium ostenfeldii (dinophyceae) affects the toxin profile. Comp. Biochem. Physiol. Vol 3, pp. 405-412.

Parker, N.S, Negri, A.P., Frampton, D.M.F., Rodolfi. L., Tredici, M.R., Blackburn, S.I., 2002 Growth of the toxic dinoflagellate Alexandrium minutum (Dinophyceae) using high biomass cultures systems. J. Appl. Phycol. 14: 313-324.

Paerl, H.W., 1988. Nuisance phytoplankton blooms in coastal, estuarine, and inland waters. Limnol. Oceanogr. 33, 823-847.

Parkhill, J.P., Cembella, A.D., 1999. Effects of salinity, light and inorganic nitrogen on growth and toxigenicity of the marine dinoflagellate Alexandrium tamarense from northeastern Canada. J.Plankton Res. 21, 939-955

Prakash, A., 1967. Growth and toxicity of a marine dinofagellate, Gonyaulax tamarensis. J. Fish. Res. Bd. Can., 24: 1589-1606.

Prakash, A., Skoglund, L., Rystad, B., Jensen, A. 1973. Growth and cell size distribution of marine planktonic algae in batch and dialysis cultures. J. Fish. Res. Bd. Can., 30: 143155.

Richard, D., Arsenault, E., Cembella, A., Quilliam, M.A., 2000. Investigations into the toxicology and pharmacology of spirolides, a novel group of shellfish toxins. In: Hallegraeff, G.M., Blackburn, S.I., Bolch, C.J.S., Lewis, R.J. (Eds.), IX International Conference on Harmful Algal Blooms. Intergovernmental Oceanographic Commission, Hobart, Australia, pp. 383-386.

Séchet, V., Berard, J., Bohec, M., Bougaran, G., Carré, C., Masselin, P., Truquet, P., 2003. Growth and toxicity of Alexandrium catenella from the Thau lagoon (France) cultured in stirred tank bioreactors. In: Villava, A., Reguera, B., Romalde, J.L., Beiras, R(Eds.), Molluscan Shellfish Safety. Intergovernmental Oceanographic Commission of UNESCO.

Schmitter, R. E., 1979. Temporary cysts of Gonyaulax excavata: effects of temperature and light. In Taylor, D. L. and Seliger, H. H. (eds), Toxic Dinoflagellate Blooms. Elsevier North Holland, New York, pp. 123.

Sleno, L., Windust, A.J., Volmer, D.A., 2004. Structural study of spirolide marine toxins by mass spectrometry. Part I. Fragmentation pathways of 13-desmethyl spirolide $C$ by collision-induced dissociation and infrared multiphoton dissociation mass spectrometry. Anal Bioanal Chem 378:969-976.

Sochet, K., Pereira, A., Braeckman, J.C., Houvenaghel, G., 1995. Growth and toxicity of Prorocentrum lima (Ehrenberg) Dodge in different culture media: effects of humic acids and organic phosphorus. In : Lassus, P., Arzul, G., le Denn, E.E, Gentien, P., Marcaillou, C (eds) Harmful marine algal blooms. Lavoisier Intercept Paris, pp 669-674.

Sullivan, J.M., Swift, E., 2003. Effects of small-scale turbulence on net growth rate and size of ten species of marine dinoflagellates. J. Phycol. 39: 83-94. 
Sullivan, J.M., Swift, E., Donaghay, P.L., Rines, J.E.B., 2003.Small-scale turbulence affects the division rate and morphology of two redtide dinoflagellates. Harmful Algae 2: 183199.

Tett, P., 1987. Modeling the growth and distribution of marine microplankton. In: Fletcher, M., Gray, T.R.G., Jones, J.G. (Eds.), Ecology of Microbial Communities, vol. 41. Cambridge University Press, Cambridge, pp. 387-425.

Tillmann, U., John, U., 2002. Toxic effects of Alexandrium spp. on heterotrophic dinoflagellates: an allelochemical defence mechanism independent of PSP toxins. Mar. Ecol. Prog. Ser., 230, 47-58.

Tillmann, U., John, U, Cembella, A.D., 2007. On the allelochemical potency of the marine dinoflagellate Alexandrium ostenfeldii against heterotrophic and autotrophic protists. J Plankton Res 29:527-543.

Villar Gonzalez, A., Rodriguez-Velasco, M.L., Ben-Gigirey, B., Botana, L.M., First evidence of spirolides in Spanish shellfi sh. Toxicon 2006; 48: 1068-1074.

Wells, M. L., Mayer, L.M., Guillard, R.R.L., 1991. Evaluation of iron as a triggering factor for red tide blooms. Mar. Ecol. Prog. Ser. 69, 93-102.

White, A.W., 1978. Salinity effects on growth and toxin content of Gonyaulax excavate, a marin dinoflagellate causing paralytic shellfish poisoning. J. Phycol. 14, 475-479.

Wright, J.L.C., Cembella, A.D., 1998. Ecophysiology and biosynthesis of polyether marine biotoxins. In: Anderson, D.M., Cembella, A.D., Hallegraeff, G.M. (Eds.), Physiological Ecology of Harmful Algal Blooms, vol. 41. Springer-Verlag, Heidelberg, pp. 427-452 NATO-Advanced Study Institute Series. 


\section{Tables}

Table 1. Structural analogues of spirolides found in A. ostenfeldii (strain CCMP1773) and respective transition fragments. $\mathrm{m} / \mathrm{z}$ (mass to charge ratio).

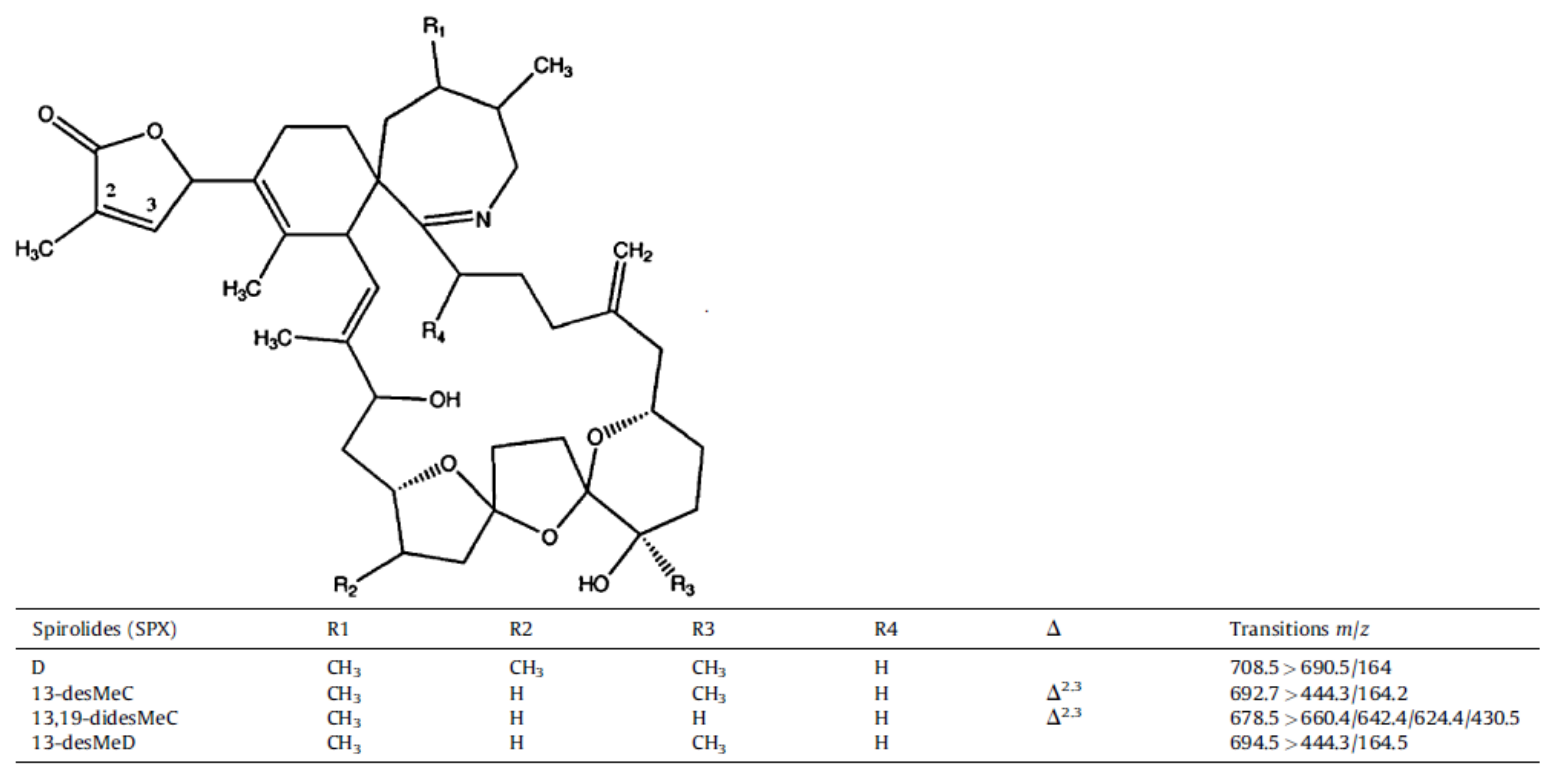

Table 2. Maximum cell concentration and growth rate for A. ostenfeldii (CCMP1773) in batch and photobioreactor cultures under different environmental conditions.

\begin{tabular}{|c|c|c|c|}
\hline \multicolumn{2}{|c|}{ Conditions } & $\begin{array}{l}\text { Maximum cell } \\
\text { concentration } \\
\left(\text { cells mL }{ }^{-1}\right)\end{array}$ & $\mu_{\max }\left(\right.$ day $\left.^{-1}\right)$ \\
\hline \multicolumn{4}{|c|}{$450 \mathrm{~mL}$ flask culture without aeration } \\
\hline \multirow[t]{3}{*}{$16^{\circ} \mathrm{C}$} & L1 & $10,560 \pm 836$ & $0.12 \pm 0.02$ \\
\hline & L1 + soil extract & $14,630 \pm 1356$ & $0.14 \pm 0.03$ \\
\hline & $f / 2$ & $12,680 \pm 790$ & $0.14 \pm 0.02$ \\
\hline \multirow[t]{3}{*}{$22^{\circ} \mathrm{C}$} & L1 & $5250 \pm 890$ & $0.08 \pm 0.02$ \\
\hline & $\mathrm{L} 1+$ soil extract & $6557 \pm 507$ & $0.1 \pm 0.03$ \\
\hline & $\mathrm{f} / 2$ & $6026 \pm 892$ & $0.10 \pm 0.02$ \\
\hline \multicolumn{4}{|c|}{ Flat bottomed vessel with aeration } \\
\hline $16^{\circ} \mathrm{C}$ & 8 L culture ( $\mathrm{L} 1+$ soil extract) & $16,788 \pm 1700$ & $0.13 \pm 0.03$ \\
\hline \multicolumn{4}{|c|}{ Photobioreactor with aeration, agitation and $\mathrm{pH}$ regulation } \\
\hline $18^{\circ} \mathrm{C}$ & $100 \mathrm{~L}$ culture $(\mathrm{L} 1+$ soil Extract) & $70,600 \pm 766$ & $0.16 \pm 0.01$ \\
\hline
\end{tabular}


Table 3. Spirolide analogue proportions and spirolide cell quota of A. ostenfeldii (CCMP1773) in batch and photobioreactor cultures under different environmental conditions.

\begin{tabular}{|c|c|c|c|c|c|c|c|}
\hline \multirow[t]{2}{*}{$T\left({ }^{\circ} \mathrm{C}\right)$} & \multirow[t]{2}{*}{ Medium/volume culture } & \multirow[t]{2}{*}{ Days } & \multicolumn{4}{|l|}{ Toxins $(\%)$} & \multirow[t]{2}{*}{ Total (pg SPX eq 13-desMeC cell ${ }^{-1}$ ) } \\
\hline & & & 13,19-didesMeC & 13-desMec & 13-desMeD & SPX-D & \\
\hline \multicolumn{8}{|c|}{ Flask cultures without aeration } \\
\hline \multirow{9}{*}{$16^{\circ} \mathrm{C}$} & L1 $450 \mathrm{~mL}$ & 3 & 29.1 & 22.2 & 20.8 & 27.8 & $4.9 \pm 0.4$ \\
\hline & & 8 & 33.3 & 22.1 & 20.1 & 24.5 & $3.9 \pm 0.3$ \\
\hline & & 16 & 37.8 & 21.5 & 18.4 & 22.3 & $1.9 \pm 0.2$ \\
\hline & $\mathrm{L} 1+$ soil extract $450 \mathrm{~mL}$ & 3 & 31.4 & 22.1 & 20.2 & 26.3 & $5.4 \pm 0.6$ \\
\hline & & 8 & 33.6 & 22.3 & 19.9 & 24.2 & $3.3 \pm 0.3$ \\
\hline & & 16 & 41.1 & 20.7 & 17.4 & 20.8 & $1.3 \pm 0.3$ \\
\hline & $\mathrm{f} / 2450 \mathrm{~mL}$ & 3 & 32.7 & 21.9 & 19.5 & 25.8 & $5.3 \pm 1$ \\
\hline & & 8 & 33.0 & 22.0 & 20.3 & 24.6 & $3.7 \pm 0.4$ \\
\hline & & 16 & 45.7 & 22.9 & 18.7 & 22.7 & $1.3 \pm 0.3$ \\
\hline \multirow[t]{9}{*}{$22^{\circ} \mathrm{C}$} & L1 $450 \mathrm{~mL}$ & 3 & 34.1 & 21.7 & 18.8 & 25.3 & $4.6 \pm 0.1$ \\
\hline & & 8 & 31.8 & 22.4 & 20.7 & 25.0 & $3.8 \pm 0.1$ \\
\hline & & 16 & 29.9 & 22.9 & 21.4 & 25.7 & $2.4 \pm 0.8$ \\
\hline & $\mathrm{L} 1+$ soil extract $450 \mathrm{~mL}$ & 3 & 32.3 & 21.9 & 19.6 & 26.2 & $4.6 \pm 0.2$ \\
\hline & & 8 & 32.1 & 22.2 & 20.5 & 25.1 & $4.3 \pm 0.2$ \\
\hline & & 16 & 34.7 & 22.3 & 19.6 & 23.3 & $2.4 \pm 0.4$ \\
\hline & $\mathrm{f} / 2450 \mathrm{~mL}$ & 3 & 29.2 & 22.1 & 20.7 & 28.0 & $4.9 \pm 0.5$ \\
\hline & & 8 & 32.3 & 22.4 & 20.5 & 24.8 & $3.5 \pm 0.4$ \\
\hline & & 16 & 32.1 & 22.6 & 20.5 & 24.8 & $2.1 \pm 0.1$ \\
\hline \multicolumn{8}{|c|}{ Flat bottomed vessels with aeration } \\
\hline \multirow[t]{4}{*}{$16^{\circ} \mathrm{C}$} & $\mathrm{L} 1+$ soil extract $8 \mathrm{~L}$ & 3 & 36.8 & 21.8 & 19.2 & 22.1 & $4.2 \pm 1$ \\
\hline & & 10 & 50.7 & 18.7 & 13.7 & 16.9 & $2.3 \pm 0.4$ \\
\hline & & 14 & 54.5 & 18.2 & 12.3 & 15.0 & $2.0 \pm 0.2$ \\
\hline & & 18 & 54.5 & 18.2 & 12.3 & 15.0 & $1.7 \pm 0.2$ \\
\hline \multicolumn{8}{|c|}{ Photobioreactor with aeration. agitation and $\mathrm{pH}$ regulation } \\
\hline \multirow[t]{13}{*}{$18^{\circ} \mathrm{C}$} & $\mathrm{L} 1+$ soil extract $100 \mathrm{~L}$ & 1 & 67.2 & 16.3 & 8.7 & 7.8 & 4.7 \\
\hline & & 5 & 68.2 & 17.3 & 7.5 & 6.9 & 2.6 \\
\hline & & 7 & 70.9 & 16.8 & 6.6 & 5.7 & 2.3 \\
\hline & & 12 & 60.2 & 17.7 & 10.4 & 11.7 & 1.1 \\
\hline & & 14 & 62.9 & 17.5 & 8.0 & 10.6 & 1.2 \\
\hline & & 20 & 68.1 & 19.7 & 6.3 & 5.8 & 1.2 \\
\hline & & 26 & 68.3 & 16.7 & 7.7 & 7.3 & 0.9 \\
\hline & & 41 & 66.7 & 15.7 & 7.3 & 10.4 & 0.8 \\
\hline & & 46 & 67.3 & 16.0 & 7.3 & 9.3 & 0.7 \\
\hline & & 62 & 74.8 & 14 & 6.3 & 4.9 & 0.8 \\
\hline & & 78 & 86.0 & 8.8 & 1.7 & 3.5 & 0.6 \\
\hline & & 98 & 87.0 & 7.9 & 1.6 & 3.4 & 0.5 \\
\hline & & 118 & 80.4 & 13.5 & 2.2 & 3.9 & 0.4 \\
\hline
\end{tabular}


Figure 1. Growth of $A$. ostenfeldii in $450 \mathrm{~mL}$ flask culture at six experimental conditions using three media (L1, L1+ soil extract, $f / 2)$ and two temperatures $\left(16\right.$ and $\left.22^{\circ} \mathrm{C}\right)$. All values are means of triplicate cultures $(n=3)$.

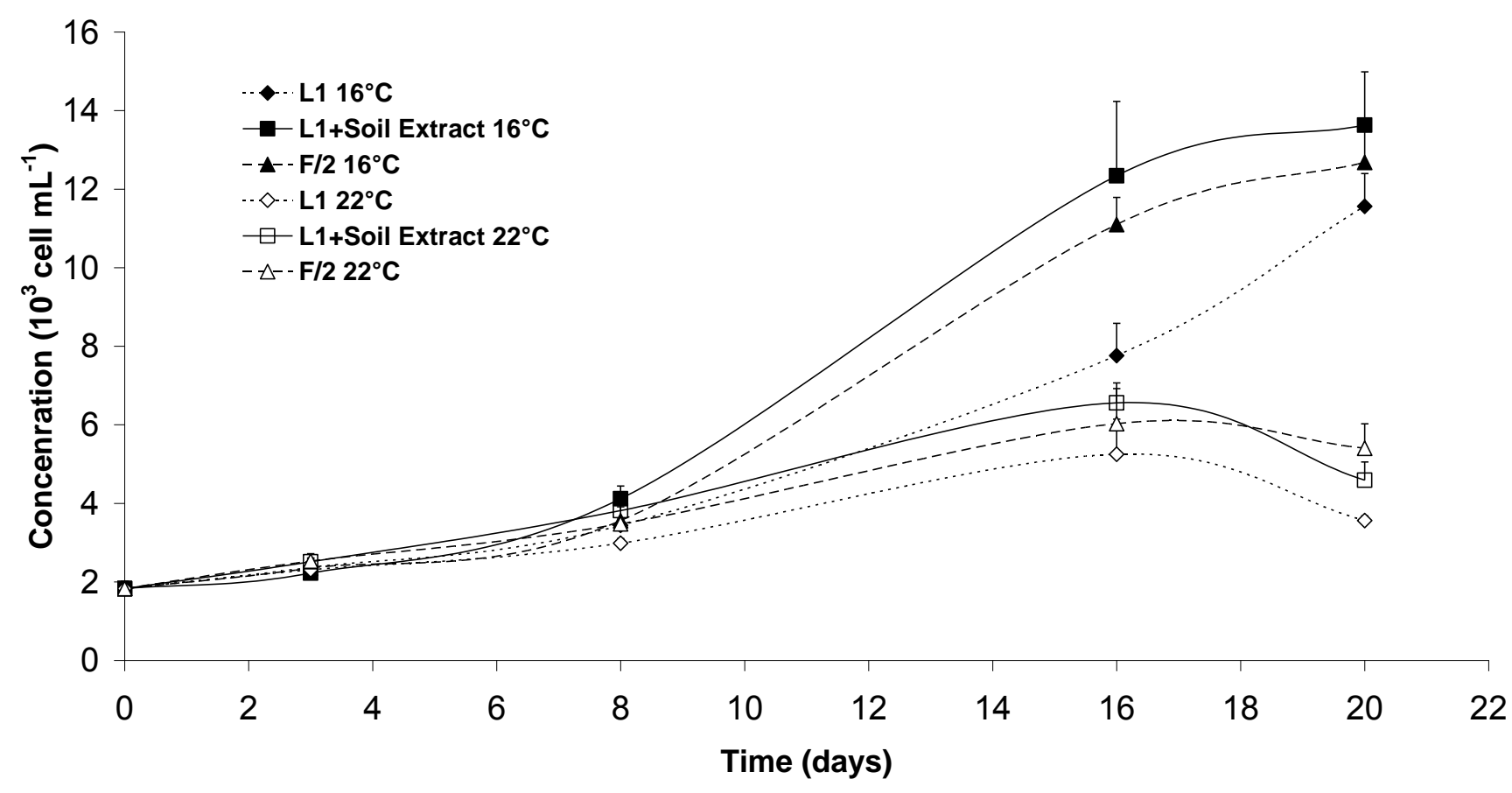

Figure 2. Cell concentrations and mean cell diameters of Alexandrium ostenfeldii during its growth in 100L-photobioreactor.

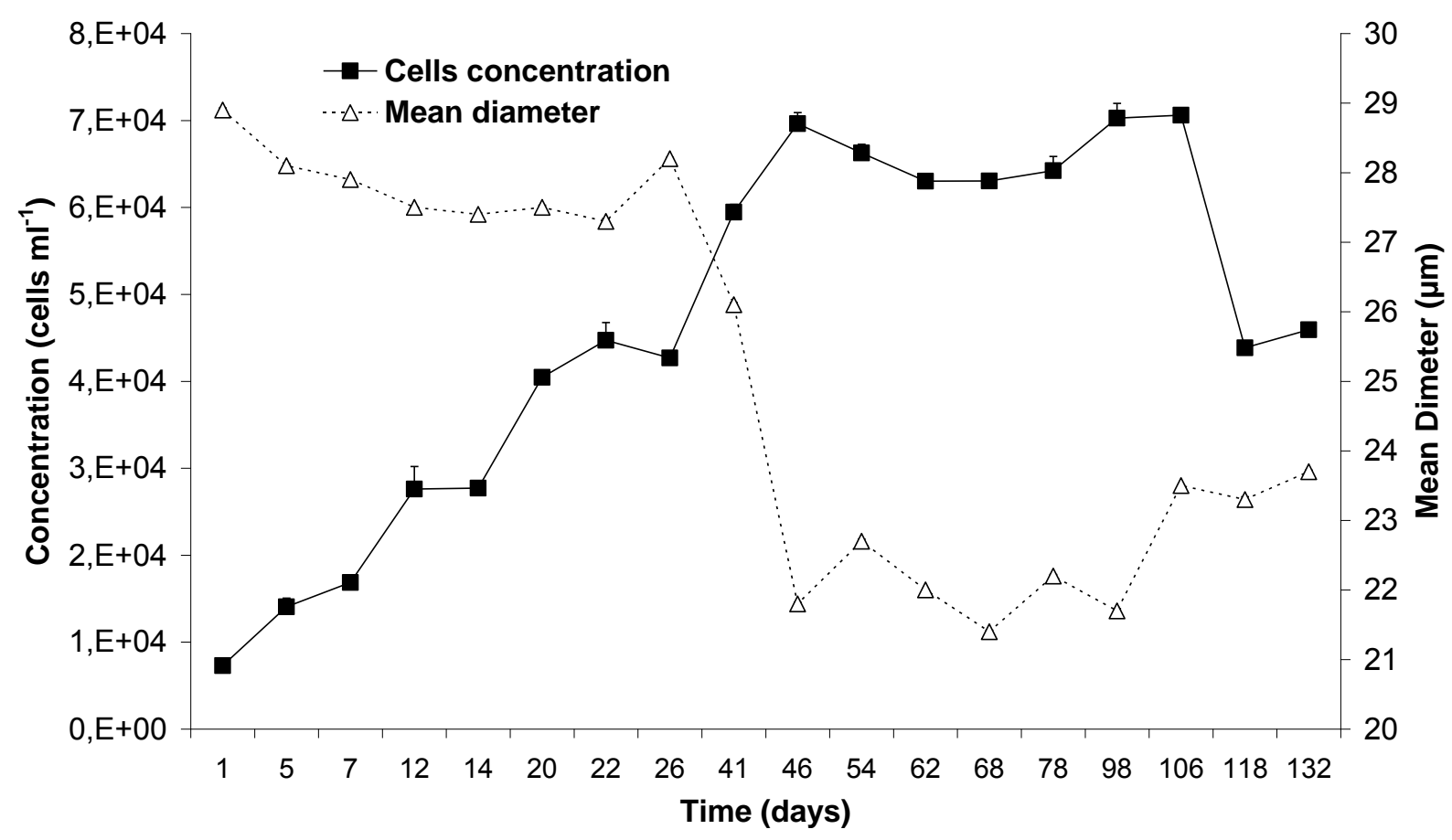


Figure 3. Mean cell diameter of Alexandrium ostenfeldii during growth in $450 \mathrm{~mL}$ flask culture under different conditions.

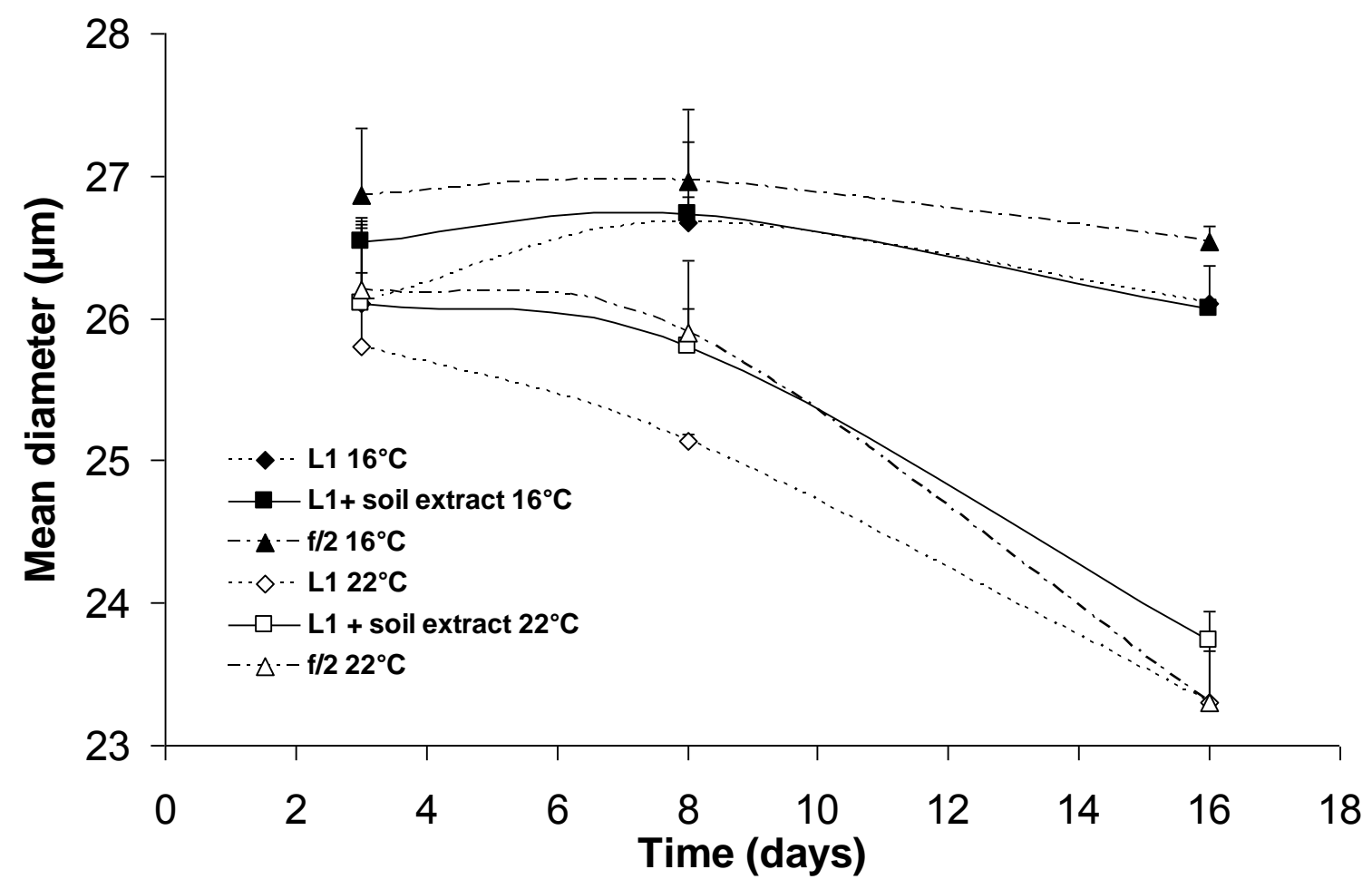


Figure 4. Cell diameter spectrum in $450 \mathrm{~mL}$ flask culture after 16 days culture at $16^{\circ} \mathrm{C}(\mathrm{A})$ and at $22^{\circ} \mathrm{C}(\mathrm{B})$. Data was collected using Coulter Counter ${ }^{\circledR}$.
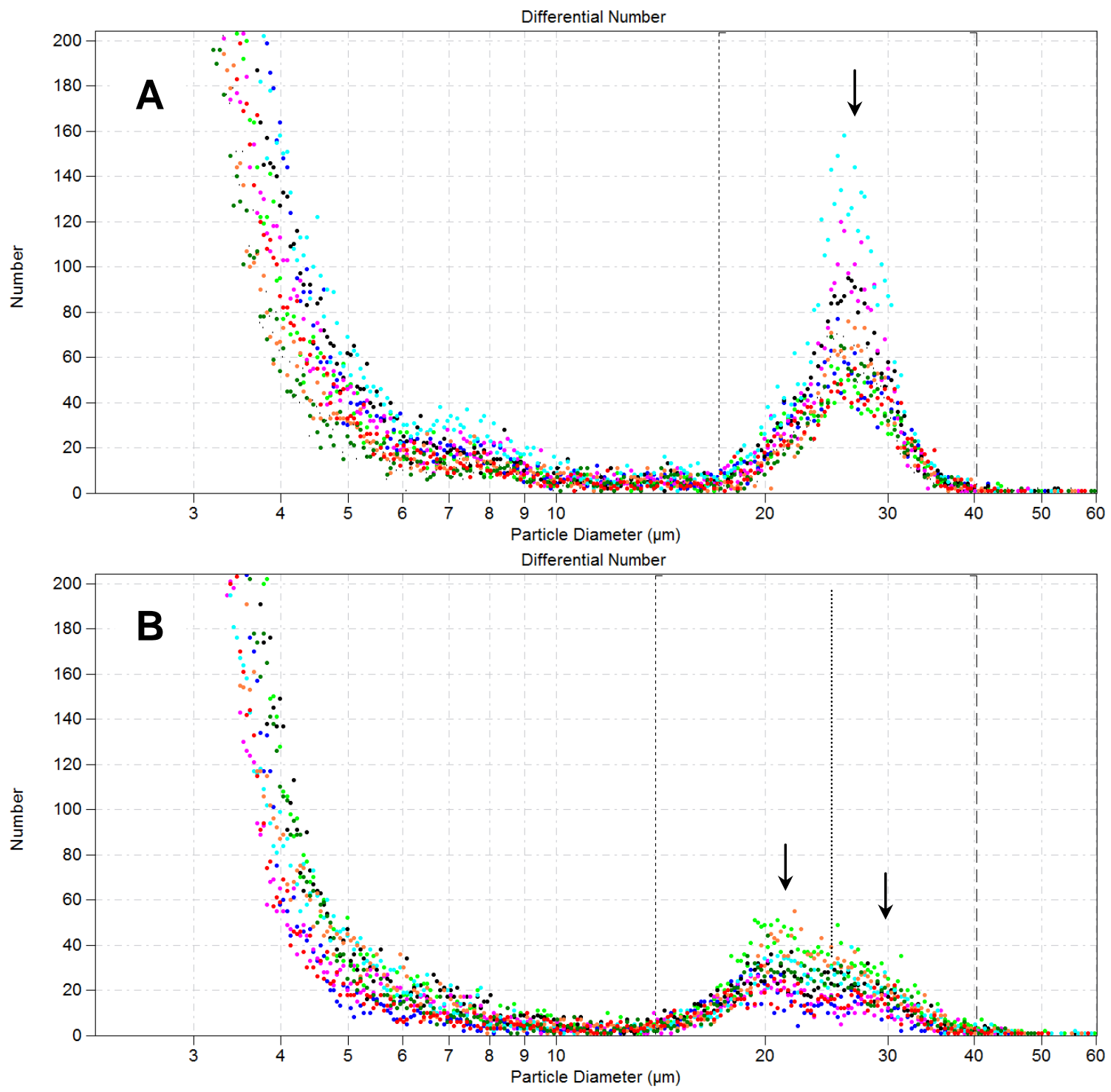

Figure 5. Cell diameter spectrum in photobioreactor culture after 34 days culture. Data was collected using Coulter Counter ${ }^{\circledR}$.

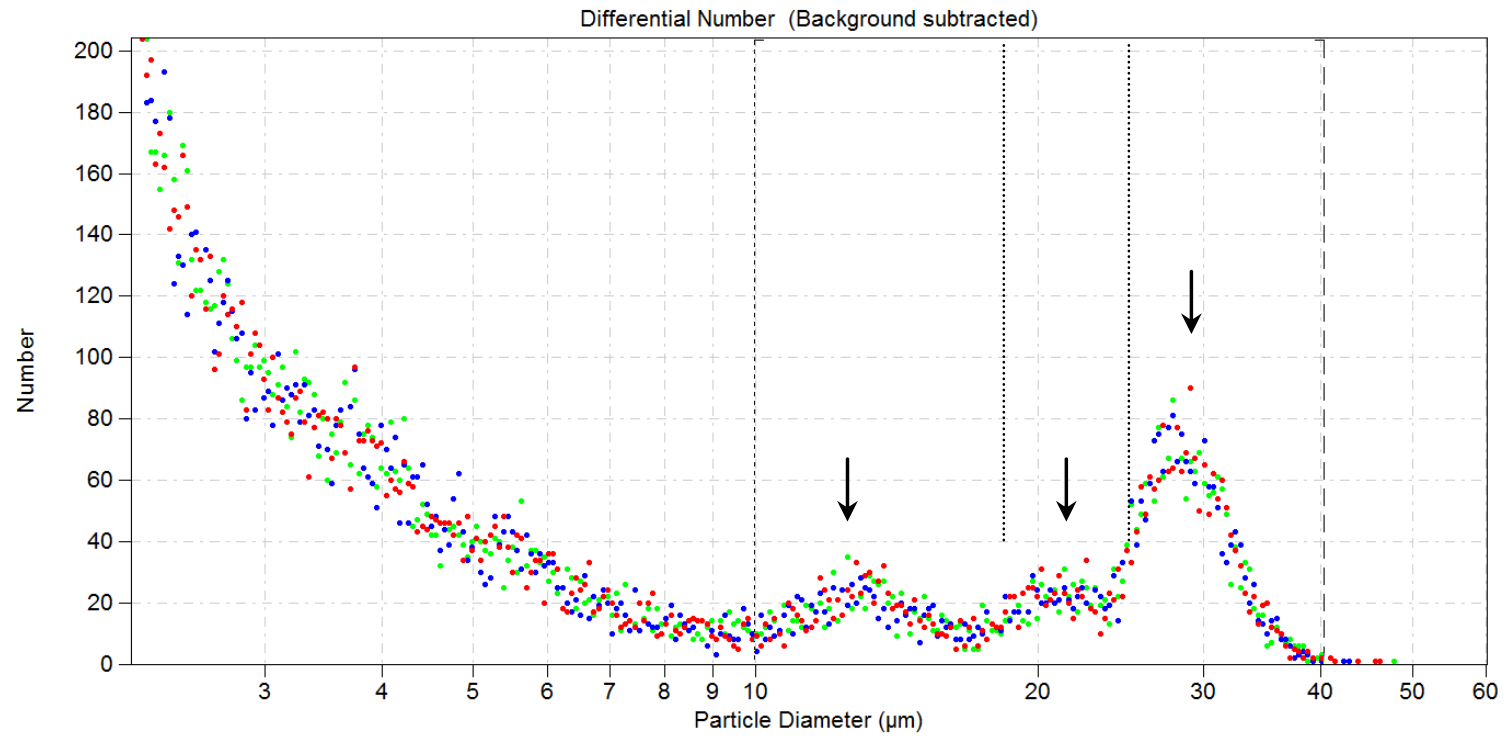


Figure 6. Inverse relationship between cell concentration and intracellular spirolide content in photobioreactor and small volume batch cultures.

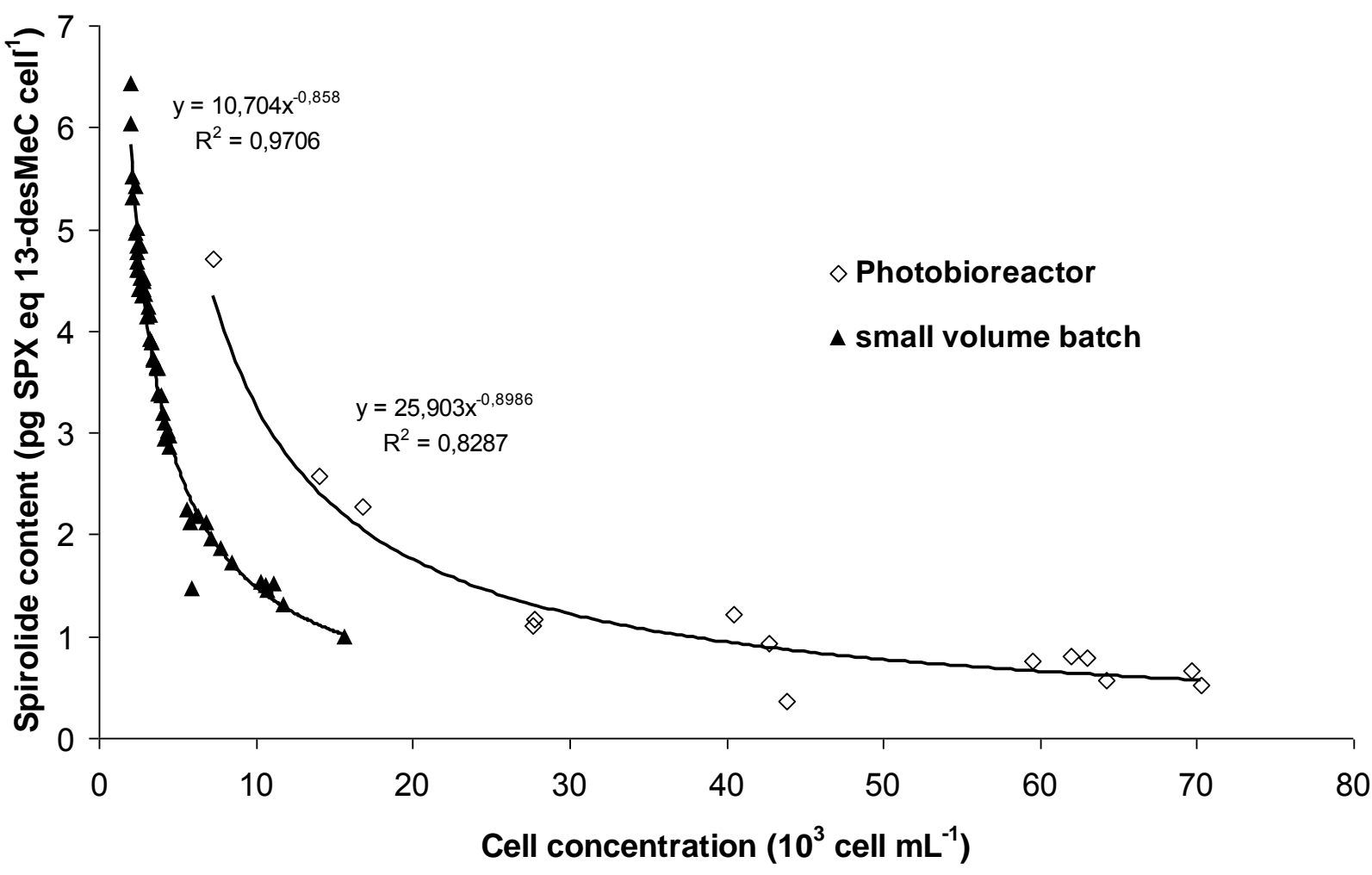


Figure 7. Relationship between cell concentration and intracellular spirolide content in small volume batch cultures under three different culture media (L1, L1+ Soil Extract, f/2) (A) and at two temperatures $\left(16^{\circ} \mathrm{C}\right.$ and $\left.22^{\circ} \mathrm{C}\right)(\mathrm{B})$.
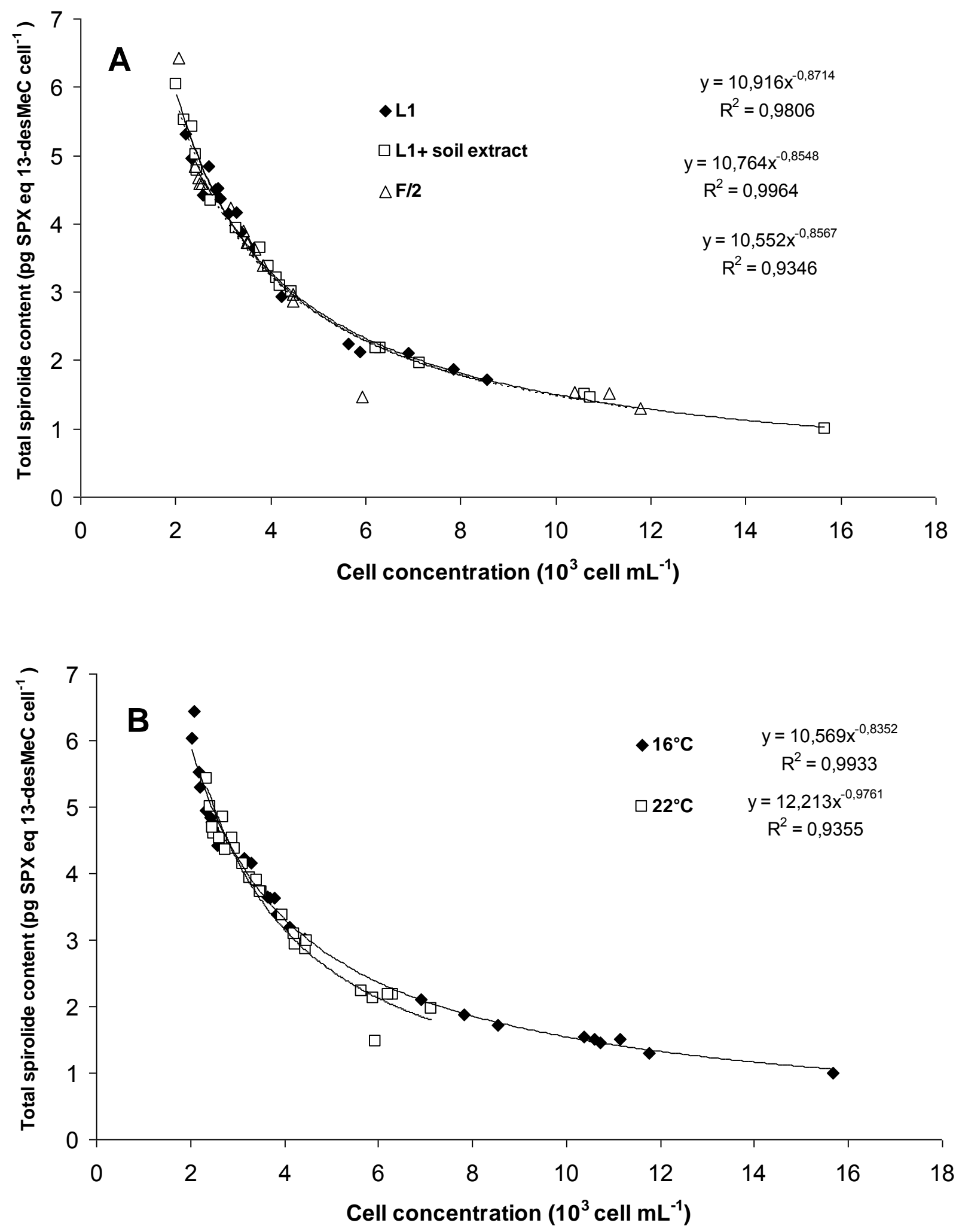
Figure 8. Variation of total spirolide concentration in the cellular fraction per unit volume of culture $(\mu \mathrm{g} / \mathrm{L})$ according to cell concentration.

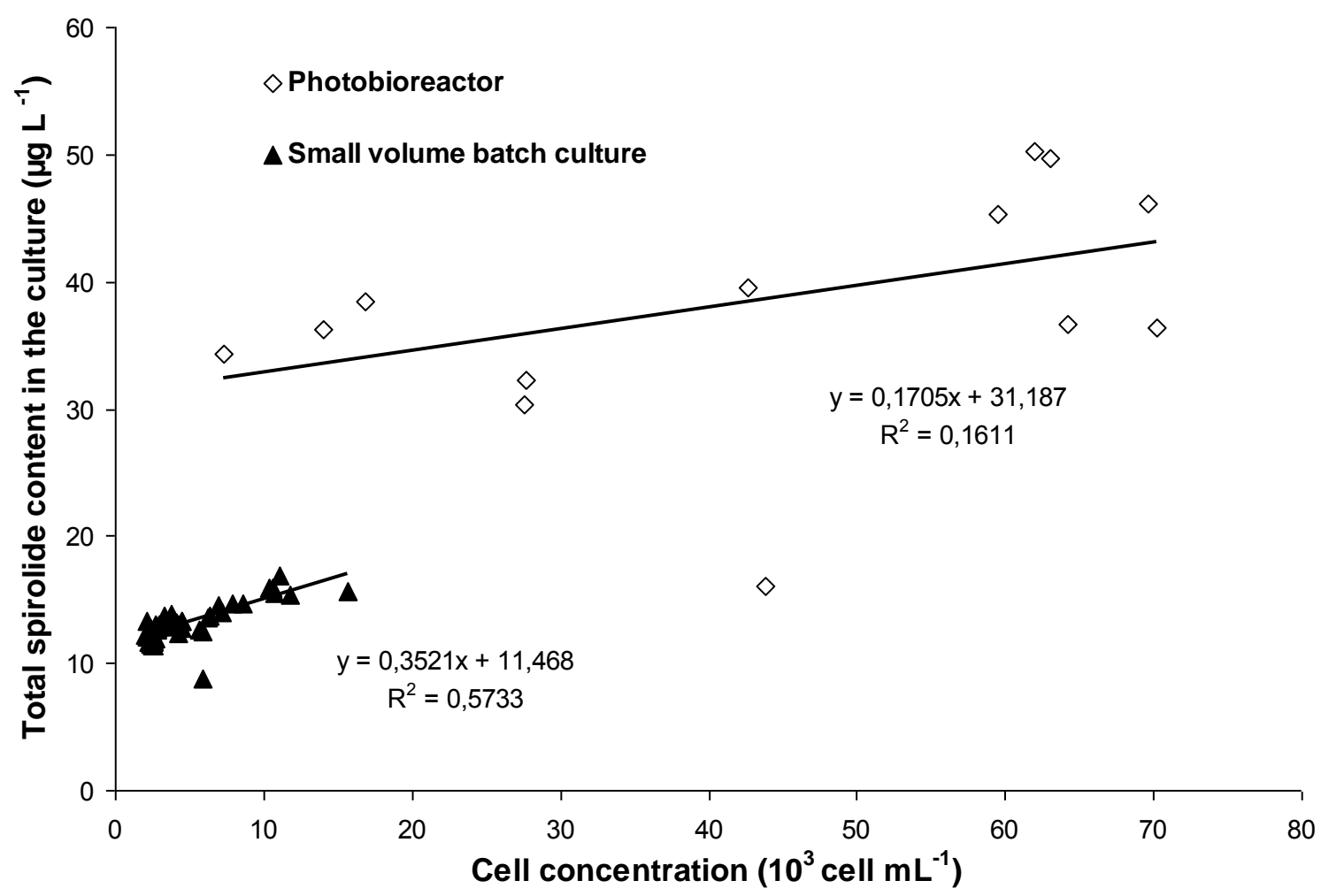

Figure 9. Variation of spirolide analogue concentrations in the cellular fraction per unit volume of culture $(\mu \mathrm{g} / \mathrm{L})$ during growth in small volume bath culture.

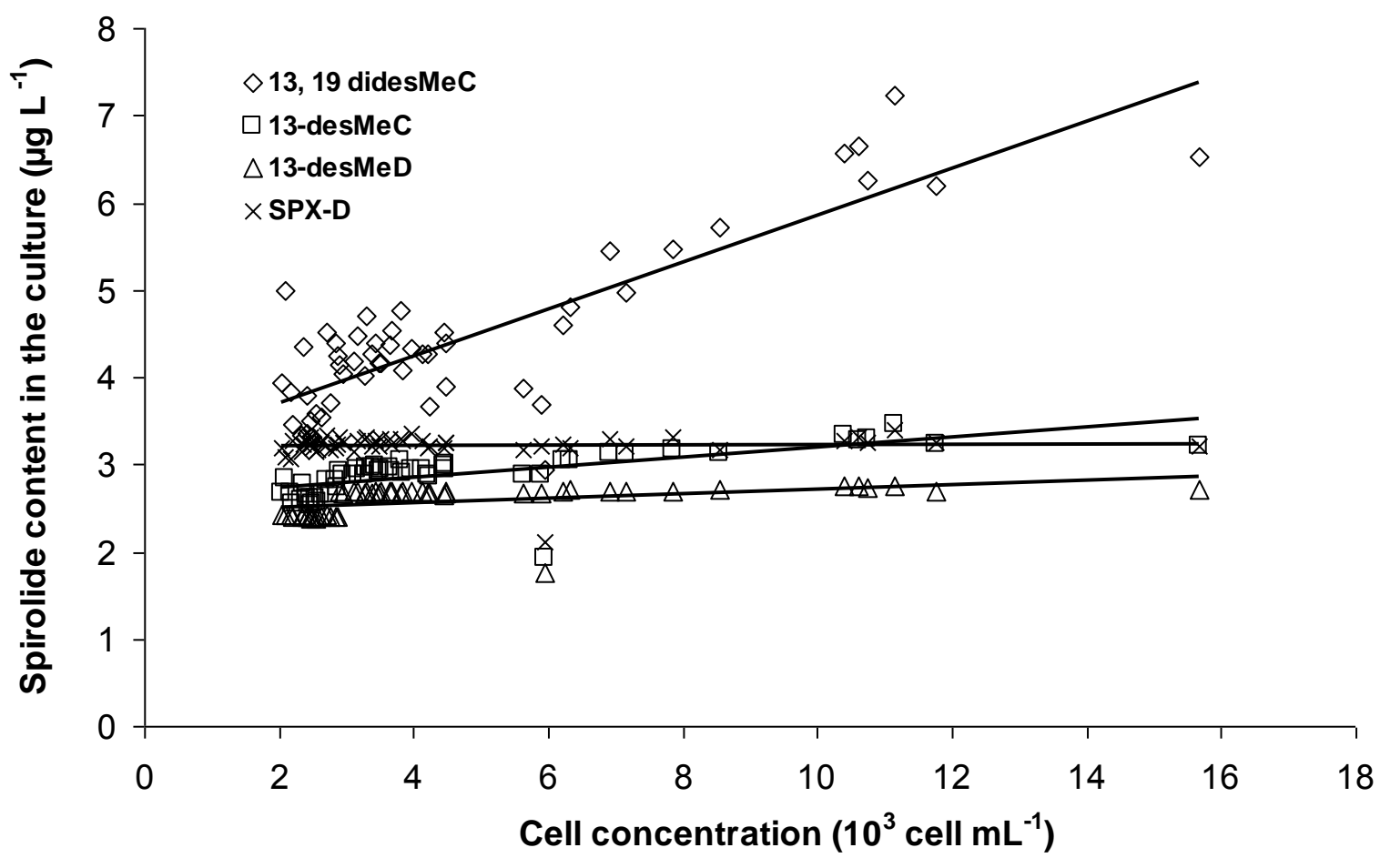


Figure 10. Variation of individual spirolide concentration in the cellular fraction per unit volume of culture $(\mu \mathrm{g} / \mathrm{L})$. Solid lines indicate the variation of the different analogues of spirolides during growth $(A)$ in exponential phase and $(B)$ in stationary phase.

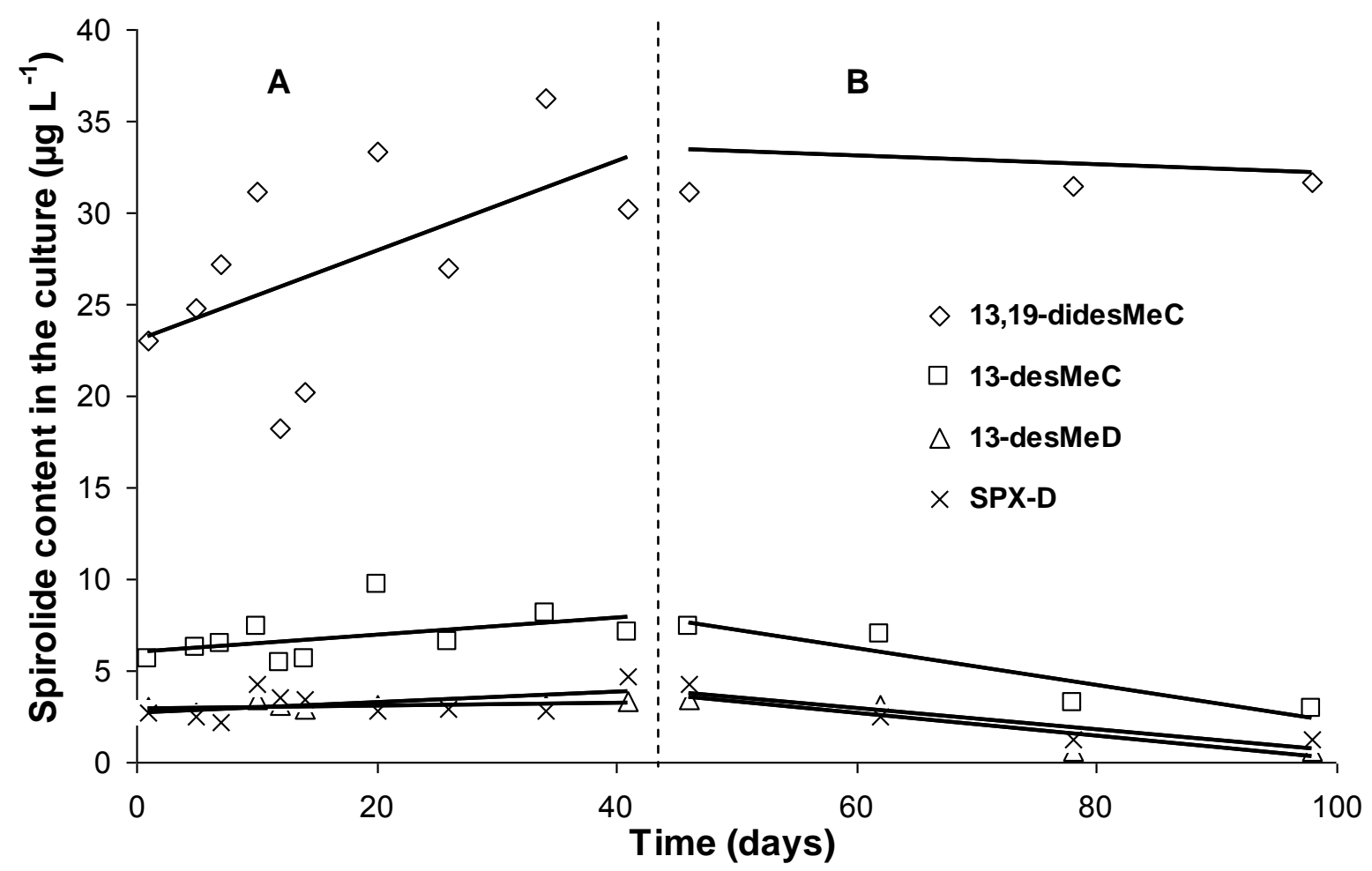

\begin{tabular}{ccccc} 
Analogues & \multicolumn{2}{c}{$\begin{array}{c}\text { Exponantial phase }(\mathbf{A}) \\
\text { Equation }\end{array}$} & $\mathbf{R}^{2}$ & \multicolumn{2}{c}{$\begin{array}{c}\text { Stationary phase (B) } \\
\text { Equation }\end{array}$} \\
13,19-didesMeC & $\mathrm{y}=0,2438 \mathrm{x}+22,991$ & $\mathrm{R}^{2}=0,3106$ & $\mathrm{y}=-0,0242 \mathrm{x}+34,583$ & $\mathrm{R}^{2}=0,0349$ \\
13-desMeC & $\mathrm{y}=0,0462 \mathrm{x}+6,0374$ & $\mathrm{R}^{2}=0,2113$ & $\mathrm{y}=-0,0995 \mathrm{x}+12,173$ & $\mathrm{R}^{2}=0,8529$ \\
13-desMeD & $\mathrm{y}=0,0098 \mathrm{x}+2,8612$ & $\mathrm{R}^{2}=0,2491$ & $\mathrm{y}=-0,0624 x+6,376$ & $\mathrm{R}^{2}=0,8175$ \\
SPX-D & $\mathrm{y}=0,0274 \mathrm{x}+2,7177$ & $\mathrm{R}^{2}=0,1999$ & $\mathrm{y}=-0,0586 \mathrm{x}+6,4791$ & $\mathrm{R}^{2}=0,8297$
\end{tabular}

